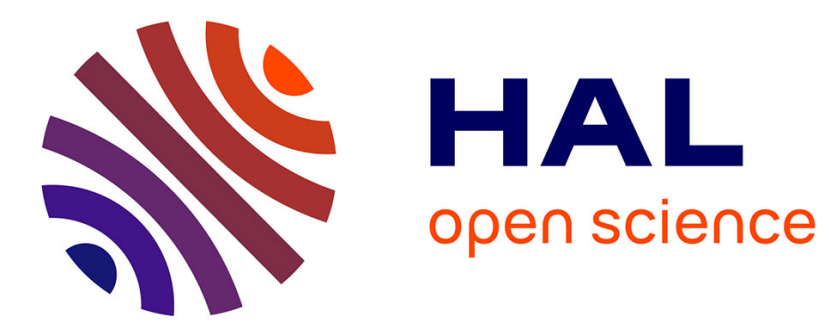

\title{
Synthesis, structure and magnetic properties of phenylhydroxamate-based coordination clusters
}

\author{
Rémi Tirfoin, Lise-Marie Chamoreau, Yanling Li, Benoit Fleury, Laurent
}

Lisnard, Yves Journaux

\section{To cite this version:}

Rémi Tirfoin, Lise-Marie Chamoreau, Yanling Li, Benoit Fleury, Laurent Lisnard, et al.. Synthesis, structure and magnetic properties of phenylhydroxamate-based coordination clusters. Dalton Transactions, 2014, 43 (44), pp.16805-16817. 10.1039/C4DT02405B . hal-01727622

\section{HAL Id: hal-01727622 \\ https://hal.science/hal-01727622}

Submitted on 23 Oct 2019

HAL is a multi-disciplinary open access archive for the deposit and dissemination of scientific research documents, whether they are published or not. The documents may come from teaching and research institutions in France or abroad, or from public or private research centers.
L'archive ouverte pluridisciplinaire HAL, est destinée au dépôt et à la diffusion de documents scientifiques de niveau recherche, publiés ou non, émanant des établissements d'enseignement et de recherche français ou étrangers, des laboratoires publics ou privés. 


\section{Synthesis, structure and magnetic properties of phenylhydroxamate- based coordination clusters ${ }^{\S}$}

Rémi Tirfoin, ${ }^{a, b}$ Lise-Marie Chamoreau, ${ }^{a, b, c}$ Yanling Li, ${ }^{a, b}$ Benoit Fleury, ${ }^{a, b}$ Laurent Lisnard, ${ }^{a, b}$ and Yves Journaux ${ }^{\star a, b}$

The strategic recombination of preformed coordination clusters in the presence of polymodal bridging ligands has successfully led to the characterisation of five new compounds of structural and magnetic interest. Indeed using the dinuclear complex $\left[\mathrm{M}_{2}\left(\mathrm{H}_{2} \mathrm{O}\right)(\text { piv })_{4}(\mathrm{Hpiv})_{4}\right](\mathrm{M}=\mathrm{Co}, \mathrm{Ni} ; \mathrm{Hpiv}=$ pivalic acid) as starting material and reacting it with phenylhydroxamic acid $\left(\mathrm{H}_{2}\right.$ pha) has yielded the four tetrametallic coordination clusters $\left[\mathrm{CO}_{4}(\mathrm{Hpha})_{2}(\text { piv })_{6}(\mathrm{Hpiv})_{4}\right](1),\left[\mathrm{Ni}_{4}(\mathrm{Hpha})_{2}(\text { piv })_{6}(\mathrm{Hpiv})_{2}(\mathrm{DMF})_{2}\right](2)$, $\left[\mathrm{CO}_{4}(\mathrm{Hpha})_{2}(\text { piv })_{6}(\mathrm{EtOH})_{2}\left(\mathrm{H}_{2} \mathrm{O}\right)_{2}\right](3),\left[\mathrm{Ni}_{4}(\mathrm{Hpha})_{2}(\text { piv })_{6}(\mathrm{EtOH})_{2}\left(\mathrm{H}_{2} \mathrm{O}\right)_{2}\right](4)$ and the hexanuclear complex $\left[\mathrm{CO}_{6}(\mathrm{Hpha})_{4}(\mathrm{piv})_{8}(\mathrm{EtOH})_{2}\right] \cdot \mathrm{EtOH}(5)$. All the compounds have been structurally characterised revealing a particular binding mode for the hydroxamate ligand. The study of their magnetic properties has been performed and the modelling of these properties has been done using the appropriate hamiltonians for each compound. The experimental data and their modellings show non-zero spin ground states for compounds 4 and 5.

\section{Introduction}

Molecule-based magnetic materials have attracted considerable interest for the past two decades. ${ }^{1}$ Indeed the existence of molecular compounds that can retain their magnetisation below a blocking or a critical temperature or else switch their magnetic state under external stimuli has motivated both chemists and physicists to further explore this area of research and its potential applications in data storage, quantum computing or spintronics. ${ }^{2}$ One particular focus has been made on discrete polymetallic compounds coordination clusters- where fundamental quantum magnetic phenomena can be observed. ${ }^{3}$ Convincing results have been obtained and ever-growing efforts are currently being made towards the comprehension of such phenomena, the structuring of the molecular systems and of course the synthesis of novel coordination clusters. ${ }^{4,5}$

One strategy to achieve the synthesis of paramagnetic coordination clusters lies in the use of specific ligands that can display multiple binding modes through distinct coordination sites and thus promote magnetic exchange between several metal ions. Indeed ligands containing $\mathrm{O}$ - and/or $\mathrm{N}$-donors such as carboxylates, poly-ols, poly-azoles or phosphonates to name a few, have efficiently led to numerous paramagnetic clusters ${ }^{6}$ including single-molecule magnets (SMM). ${ }^{4 a, c, d}$ To this end, hydroxamic acids constitute excellent candidates for the preparation of coordination clusters as demonstrated by V. Pecoraro's group work on metallacrowns which includes examples of SMMs. ${ }^{7,8}$ Another known strategy for the preparation of magnetic coordination compounds is based on the use of pre-formed clusters. Used as reactants, specific clusters can be assembled into higher nuclearity complexes or into extended structures, they can be used to incorporate co-ligands or additional metal ions or they can simply represent handy and/or reactive precursors in comparison to commercial sources. There are now several examples of pre-formed carboxylato clusters that have been used either as starting materials or building blocks to generate macromolecular, supramolecular or multidimensional assemblies. ${ }^{9}$ Similarly arrays of topologically SMM-like molecules have been obtained from in-situ preparation of the polymetallic building blocks and further linking with organic or inorganic spacers. ${ }^{10}$

Aiming at the synthesis of novel magnetic coordination clusters we have combined the two strategies mentioned above in studying the reactivity of phenylhydroxamic acid, $\mathrm{H}_{2}$ pha, with the preformed bimetallic complex, $\left[\mathrm{M}_{2}\left(\mathrm{H}_{2} \mathrm{O}\right)(\text { piv })_{4}(\mathrm{Hpiv})_{4}\right]\left\{\mathrm{M}_{2}\right.$ piv\} (Hpiv: trimethylacetic acid, $\left.\mathrm{M}=\mathrm{Co}^{11}, \mathrm{Ni}^{12}\right)$. Surprisingly the $\mathrm{H}_{2}$ pha ligand 
has scarcely been used in the synthesis of coordination clusters and only a limited number of clusters containing paramagnetic early transition metal ions have been reported. ${ }^{13}$ Both the cobalt(II) and nickel(II) pivalate dimers have been successfully used as starting materials to build coordination clusters. ${ }^{9 h, 9 i, 9 k, 11,12,14,15,16}$ In particular, the cobalt(II) dimer alone is known to recombine in solution yielding homo- and hetero-valent species with nuclearities ranging from three to fourteen cobalt ions. ${ }^{11}$ Its use in the presence of additional bridging ligands has also led to single-molecule magnets $^{14 \mathrm{e}}$ as well as remarkable nanosized clusters. ${ }^{14 f}$ Moreover the unique and appealing magnetic properties of the cobalt(II) ion has in recent years motivated numerous research on the synthesis of cobalt-based coordination clusters. ${ }^{17,18}$ Besides, cobalt-based coordination clusters are also receiving considerable attention in water oxidation catalysis. ${ }^{19}$

Herein we report the synthesis, the structural characterisation and the magnetic properties of five coordination clusters we have obtained reacting $\mathrm{H}_{2}$ pha with either $\left\{\mathrm{Co}_{2}\right.$ piv $\}$ or $\left\{\mathrm{Ni}_{2}\right.$ piv $\}$. Coordination of the $\mathrm{H}_{2}$ pha ligand has led to a recombination of the dinuclear building blocks which, upon varying solvent and base, has afforded the four tetrametallic clusters [ $\left.\mathrm{CO}_{4}(\mathrm{Hpha})_{2}(\text { piv })_{6}(\mathrm{Hpiv})_{4}\right]$ (1), [ $\left.\mathrm{Ni}_{4}(\mathrm{Hpha})_{2}(\mathrm{piv})_{6}(\mathrm{Hpiv})_{2}(\mathrm{DMF})_{2}\right]$ (2), $\left[\mathrm{CO}_{4}(\mathrm{Hpha})_{2}(\text { piv })_{6}(\mathrm{EtOH})_{2}\left(\mathrm{H}_{2} \mathrm{O}\right)_{2}\right]$ (3), $\left[\mathrm{Ni}_{4}(\mathrm{Hpha})_{2}(\mathrm{piv})_{6}(\mathrm{EtOH})_{2}\left(\mathrm{H}_{2} \mathrm{O}\right)_{2}\right]$ (4) and the hexanuclear complex $\left[\mathrm{Co}_{6}(\mathrm{Hpha})_{4}(\mathrm{piv})_{8}(\mathrm{EtOH})_{2}\right] \cdot \mathrm{EtOH}(5)$.

\section{Experimental}

Synthesis

All reagents were used as purchased with no further purification.

$\left[\mathrm{Co}_{2}\left(\mathrm{H}_{2} \mathrm{O}\right)\left(\mathrm{O}_{2} \mathrm{CCMe}_{3}\right)_{4}\left(\mathrm{HO}_{2} \mathrm{CCMe}_{3}\right)_{4}\right],\left\{\mathrm{Co}_{2}\right.$ piv\}, was prepared according to the literature procedure. ${ }^{11}$ Elemental analysis (\%) calculated for $\mathrm{C}_{40} \mathrm{H}_{78} \mathrm{Co}_{2} \mathrm{O}_{17}\left(\mathrm{M}_{\mathrm{r}}=948.9 \mathrm{~g} \mathrm{~mol}^{-1}\right)$ : $\mathrm{C} 50.63, \mathrm{H}$ 8.29. Found: $\mathrm{C} \mathrm{50.46,} \mathrm{H} \mathrm{8.25.}$

$\left[\mathrm{Ni}_{2}\left(\mathrm{H}_{2} \mathrm{O}\right)\left(\mathrm{O}_{2} \mathrm{CCMe}_{3}\right)_{4}\left(\mathrm{HO}_{2} \mathrm{CCMe}_{3}\right)_{4}\right],\left\{\mathrm{Ni}_{2}\right.$ piv $\}$, was prepared according to the literature procedure. ${ }^{12}$ Elemental analysis (\%) calculated for $\mathrm{C}_{40} \mathrm{H}_{78} \mathrm{Ni}_{2} \mathrm{O}_{17}\left(\mathrm{M}_{\mathrm{r}}=948.4 \mathrm{~g} \mathrm{~mol}^{-1}\right)$ : $\mathrm{C} 50.65, \mathrm{H}$ 8.29. Found: C 50.44, H 8.24.

Hydrate phenylhydroxamic acid, $\mathrm{H}_{2}$ pha $\cdot 1.5 \mathrm{H}_{2} \mathrm{O}$, was prepared by a modification of the literature procedure. ${ }^{20}$ Sodium hydroxide $(43.7 \mathrm{~g}, 1.093 \mathrm{~mol}$ ) dissolved in $100 \mathrm{~mL}$ of water was added to an aqueous solution $(100 \mathrm{~mL})$ of hydroxylamine hydrochloride $(38 \mathrm{~g}, 0.546 \mathrm{~mol})$. The mixture was stirred for $15 \mathrm{~min}$ and then added to an ethanolic solution $(200 \mathrm{~mL})$ of ethyl benzoate $(41 \mathrm{~g}, 0.273 \mathrm{~mol})$. The resulting solution was stirred for $72 \mathrm{hrs}$ at $40^{\circ} \mathrm{C}$ under inert atmosphere and left to cool to room temperature. $\mathrm{pH}$ was adjusted to 2 with $37 \% \mathrm{HCl}$ and a yellow precipitate was obtained after evaporation of the solvents under vacuum. The crude product was dissolved in $250 \mathrm{~mL}$ of absolute ethanol and the solution filtered to remove the $\mathrm{NaCl}$ precipitate that was formed. Further evaporation of the solvent under vacuum has yielded a white powder that was recrystallised from hot water. Yield: $29 \mathrm{~g}(78 \%)$. RMN ${ }^{1} \mathrm{H}(400 \mathrm{MHz}, \mathrm{DMSO}, 298 \mathrm{~K}, \delta): 7.45\left(2 \mathrm{H}, \mathrm{t},{ }^{1} \mathrm{~J}=7.4 \mathrm{~Hz}, \mathrm{Ph}\right) ; 7.51(1 \mathrm{H}$, $\left.\mathrm{t},{ }^{1} \mathrm{~J}=7.2 \mathrm{~Hz}, \mathrm{Ph}\right) ; 7.76\left(2 \mathrm{H}, \mathrm{d},{ }^{1} \mathrm{~J}=7.76 \mathrm{~Hz}, \mathrm{Ph}\right) ; 11.23(1 \mathrm{H}, \mathrm{s}, \mathrm{NH}) . \mathrm{RMN}{ }^{13} \mathrm{C}(400 \mathrm{MHz}, \mathrm{DMSO}, 298 \mathrm{~K}, \delta):$ $126.82 ; 128.33 ; 131.09 ; 132.73 ; 164,20$. Elemental analysis (\%) calculated for $\mathrm{C}_{7} \mathrm{H}_{10} \mathrm{NO}_{3,5}\left(\mathrm{M}_{\mathrm{r}}=164.16 \mathrm{~g} \cdot \mathrm{mol}^{-1}\right)$ : $\mathrm{C}$, 51.2; H, 6.1; N, 8.5. Found: C, 51.1; H, 5.9; N, 8.5. ATR/FT-IR $\left(\mathrm{cm}^{-1}\right): 3283 \mathrm{~s} ; 3030 \mathrm{w} ; 2693 \mathrm{br} ; 1642 \mathrm{~m} ; 1622 \mathrm{w}$; $1601 \mathrm{~s} ; 1554 \mathrm{~s} ; 1488 \mathrm{~m} ; 1452 \mathrm{~m} ; 1433 \mathrm{~m} ; 1326 \mathrm{w} ; 1314 \mathrm{~s} ; 1302 \mathrm{sh} ; 1185 \mathrm{w} ; 1160 \mathrm{~m} ; 1077 \mathrm{w} ; 1039 \mathrm{w} ; 1020 \mathrm{w} ; 930 \mathrm{w}$; 896m; 796m; 786m; 704w; 687s; 674m; 618w; 513s; 486s; 426s; 368s; 332m; 291sh; 282m.

$\left[\mathrm{CO}_{4}(\mathrm{Hpha})_{2}(\mathrm{piv})_{6}(\mathrm{Hpiv})_{4}\right](1)$.

$\mathrm{H}_{2}$ pha $\cdot 1.5 \mathrm{H}_{2} \mathrm{O}(0.041 \mathrm{~g}, 0.25 \mathrm{mmol})$ and $\left\{\mathrm{Co}_{2}\right.$ piv\} $(0.237 \mathrm{~g}, 0.25 \mathrm{mmol})$ were dissolved in $\mathrm{MeOH}(20 \mathrm{~mL})$ and the mixture was stirred overnight. The resulting purple solution was left to slowly evaporate at room temperature. After eight weeks purple crystals of 1 were collected by filtration and dried in air. Yield: $0.073 \mathrm{~g} \mathrm{(38 \%} \mathrm{based} \mathrm{on}$ Co). Elemental analysis (\%) calculated for $\mathrm{C}_{64} \mathrm{H}_{106} \mathrm{Co}_{4} \mathrm{~N}_{2} \mathrm{O}_{24}\left(\mathrm{M}_{\mathrm{r}}=1523.2 \mathrm{~g} \mathrm{~mol}^{-1}\right): \mathrm{C}, 50.4 ; \mathrm{H}, 7.0 ; \mathrm{N}, 1.8$; Co, 15.5. Found: C, 50.3; H, 7.0; N, 1.8; Co, 15.3. ATR/FT-IR $\left(\mathrm{cm}^{-1}\right): 3372 \mathrm{w} ; 2960(\mathrm{~m}) ; 2931 \mathrm{w} ; 2872 \mathrm{w} ; 2579 \mathrm{br}$; $1686 \mathrm{~m} ; 1614 \mathrm{~s} ; 1604 \mathrm{sh} ; 1572 \mathrm{sh} ; 1519 \mathrm{~m} ; 1480 \mathrm{~s} ; 1460 \mathrm{w} ; 1410 \mathrm{~s} ; 1357 \mathrm{~s} ; 1315 \mathrm{~m} ; 1223 \mathrm{sh} ; 1199 \mathrm{~s} ; 1157 \mathrm{w} ; 1078 \mathrm{w}$; 1025 w; 936sh; 914w; 897w; 872w; 796sh; 786m; 766w; 712m; 697w; 683m; 603m; 574w; 538m; 482m; 412m; $393 \mathrm{~m} ; 371 \mathrm{w} ; 302 \mathrm{w}$.

$\left[\mathrm{Ni}_{4}(\mathrm{Hpha})_{2}(\text { piv })_{6}(\mathrm{Hpiv})_{2}(\mathrm{DMF})_{2}\right](2)$. 
$\mathrm{H}_{2}$ pha $1.5 \mathrm{H}_{2} \mathrm{O}(0.041 \mathrm{~g}, 0.25 \mathrm{mmol})$ and $\left\{\mathrm{Ni}_{2}\right.$ piv $\}(0.237 \mathrm{~g}, 0.25 \mathrm{mmol})$ were dissolved in DMF $(15 \mathrm{~mL})$ followed by the addition of triethylamine $(0.036 \mathrm{~mL}, 0.25 \mathrm{mmol})$. The mixture was stirred overnight and the resulting green solution left to slowly evaporate at room temperature. After six weeks green crystals of 2 were collected by filtration and dried in air. Yield: $0.086 \mathrm{~g}(47 \%$ based on $\mathrm{Ni})$. Elemental analysis (\%) calculated for $\mathrm{C}_{60} \mathrm{H}_{100} \mathrm{~N}_{4} \mathrm{Ni}_{4} \mathrm{O}_{22}\left(\mathrm{M}_{\mathrm{r}}=1464.2 \mathrm{~g} \mathrm{~mol}^{-1}\right): \mathrm{C}, 49.2 ; \mathrm{H}, 6.9 ; \mathrm{N}, 3.8 ; \mathrm{Ni}, 16.0$. Found: $\mathrm{C}, 48.5 ; \mathrm{H}, 6.8 ; \mathrm{N}, 4.4 ; \mathrm{Ni}, 16.2$. ATR/FT-IR $\left(\mathrm{cm}^{-1}\right): 3326 \mathrm{w} ; 2956 \mathrm{~m} ; 2926 \mathrm{w} ; 2906 \mathrm{sh} ; 2869 \mathrm{w} ; 1689 \mathrm{sh} ; 1664 \mathrm{~m} ; 1615 \mathrm{~s} ; 1586 \mathrm{w} ; 1572 \mathrm{w} ; 1555 \mathrm{sh}$; $1524 \mathrm{~m} ; 1481 \mathrm{~s} ; 1461 \mathrm{w} ; 1448 \mathrm{w} ; 1416 \mathrm{~s} ; 1371 \mathrm{w} ; 1354 \mathrm{w} ; 1324 \mathrm{w} ; 1260 \mathrm{w} ; 1228 \mathrm{~m} ; 1208 \mathrm{~m} ; 1158 \mathrm{~m} ; 1100 \mathrm{~m} ; 935 \mathrm{w}$; 915w; 894w; 873w; 797w; 787m; 771w; 713m; 685s; 606m; 587w; 566w; 538w; 504w; 455w; 414m; 401w; $371 w ; 318 m ; 275 w ; 229 m$.

$\left[\mathrm{CO}_{4}(\mathrm{Hpha})_{2}(\mathrm{piv})_{6}(\mathrm{EtOH})_{2}\left(\mathrm{H}_{2} \mathrm{O}\right)_{2}\right](3)$.

$\mathrm{H}_{2}$ pha $1.5 \mathrm{H}_{2} \mathrm{O}(0.041 \mathrm{~g}, 0.25 \mathrm{mmol})$ and $\left\{\mathrm{Co}_{2}\right.$ piv $\}(0.237 \mathrm{~g}, 0.25 \mathrm{mmol})$ were dissolved in $\mathrm{EtOH}(20 \mathrm{~mL})$ followed by the addition of tetrabutylammonium hydroxide ( $1 \mathrm{M}$ in $\mathrm{MeOH}, 0.25 \mathrm{~mL}, 0.25 \mathrm{mmol})$. The mixture was stirred overnight and the resulting purple solution left to slowly evaporate at room temperature. After eight weeks pink crystals of 3 were collected by filtration and dried in air. Yield: $0.071 \mathrm{~g}$ ( $43 \%$ based on Co). Elemental analysis (\%) calculated for $\mathrm{C}_{48} \mathrm{H}_{82} \mathrm{Co}_{4} \mathrm{~N}_{2} \mathrm{O}_{20}\left(\mathrm{M}_{\mathrm{r}}=1242.9 \mathrm{~g} \mathrm{~mol}^{-1}\right)$ : $\mathrm{C}, 46.4 ; \mathrm{H}, 6.6 ; \mathrm{N}, 2.2 ;$. Found: $\mathrm{C}, 46.3 ; \mathrm{H}, 6.7$; $\mathrm{N}$, 2.3. ATR/FT-IR $\left(\mathrm{cm}^{-1}\right): 3345,84(\mathrm{f}) ; 2959 \mathrm{~m} ; 2928 \mathrm{w} ; 2904 \mathrm{w} ; 2868 \mathrm{w} ; 1674 \mathrm{w} ; 1599 \mathrm{~s} ; 1566 \mathrm{sh} ; 1539 \mathrm{w} ; 1521 \mathrm{w}$; $1482 \mathrm{~s} ; 1457 \mathrm{w} ; 1417 \mathrm{~s} ; 1374 \mathrm{sh} ; 1361 \mathrm{~m} ; 1324 \mathrm{w} ; 1259 \mathrm{w} ; 1226 \mathrm{~s} ; 1207 \mathrm{sh} ; 1157 \mathrm{w} ; 1088 \mathrm{~m} ; 1051 \mathrm{~m} ; 1026 \mathrm{w} ; 910 \mathrm{~m}$; 893m; 805sh; 786m; 708w; 684w; 603m; 556w; 491m; 409m; 392m.

\begin{tabular}{|c|c|c|c|c|}
\hline & 1 & 2 & 3 & 5 \\
\hline Formula $^{\mathrm{a}}$ & $\mathrm{C}_{64} \mathrm{H}_{106} \mathrm{Co}_{4} \mathrm{~N}_{2} \mathrm{O}_{24}$ & $\mathrm{C}_{60} \mathrm{H}_{100} \mathrm{~N}_{4} \mathrm{Ni}_{4} \mathrm{O}_{22}$ & $\mathrm{C}_{48} \mathrm{H}_{82} \mathrm{Co}_{4} \mathrm{~N}_{2} \mathrm{O}_{20}$ & $\mathrm{C}_{74} \mathrm{H}_{114} \mathrm{Co}_{6} \mathrm{~N}_{4} \mathrm{O}_{27}$ \\
\hline$F . W .\left[\mathrm{g} \mathrm{mol}^{-1}\right]$ & 1523.2 & 1464.2 & 1242.9 & 1845.3 \\
\hline Crystal system & Triclinic & Triclinic & Triclinic & Monoclinic \\
\hline Space group & $P-1$ & $P-1$ & $P-1$ & $C 2 / c$ \\
\hline$a[\AA]$ & $12.1420(5)$ & $11.8753(4)$ & $10.9832(2)$ & $26.774(2)$ \\
\hline$b[\AA]$ & $13.3720(5)$ & $13.2048(4)$ & $12.7170(2)$ & $13.963(1)$ \\
\hline$c[\AA]$ & $14.1654(6)$ & $13.8854(5)$ & $13.1082(1)$ & $25.509(2)$ \\
\hline$\alpha\left[^{\circ}\right]$ & $62.550(2)$ & $62.403(1)$ & $114.643(1)$ & 90 \\
\hline$\beta\left[^{\circ}\right]$ & $80.916(2)$ & $82.791(1)$ & $98.680(1)$ & $102.481(5)$ \\
\hline$\gamma\left[^{\circ}\right]$ & $71.263(2)$ & $69.928(1)$ & $106.364(1)$ & 90 \\
\hline$V\left[\AA^{3}\right]$ & $1932.70(14)$ & $1810.99(10)$ & $1519.21(4)$ & 9311(1) \\
\hline$Z$ & 1 & 1 & 1 & 4 \\
\hline$T[\mathrm{~K}]$ & $200(2)$ & $200(2)$ & $200(2)$ & $200(2)$ \\
\hline$\lambda[\AA]$ & 0.71073 & 0.71073 & 0.71073 & 0.71073 \\
\hline$\rho_{\text {calc }}\left[\mathrm{g} \mathrm{cm}^{-3}\right]$ & 1.309 & 1.343 & 1.358 & 1.349 \\
\hline$\mu\left(\mathrm{Mo}_{\mathrm{K}}\right)\left[\mathrm{mm}^{-1}\right]$ & 0.914 & 1.095 & 1.141 & 1.117 \\
\hline Measured reflections & 35172 & 33162 & 23018 & 49173 \\
\hline Unique reflections & 8772 & 10630 & 8871 & 13563 \\
\hline$R_{\text {int }}$ & 0.0271 & 0.0264 & 0.0188 & 0.0401 \\
\hline Reflections $\mathrm{I}>2 \sigma(\mathrm{I})$ & 7532 & 8011 & 7250 & 9251 \\
\hline Parameters & 540 & 420 & 391 & 590 \\
\hline Restraints & 219 & 0 & 155 & 102 \\
\hline$R_{I}^{b}[\mathrm{I}>2 \sigma(\mathrm{I})]$ & 0.0528 & 0.0446 & 0.0309 & 0.0398 \\
\hline$w R_{2}^{c}[\mathrm{I}>2 \sigma(\mathrm{I})]$ & 0.1549 & 0.1185 & 0.0795 & 0.0971 \\
\hline GOF & 1.042 & 1.023 & 1.015 & 1.001 \\
\hline Largest residuals $\left[\mathrm{e} \AA^{3}\right]$ & $-0.652 ; 1.175$ & $-0.835 ; 0.765$ & $-0.405 ; 0.536$ & $-0.383 ; 0.442$ \\
\hline
\end{tabular}

$\left[\mathrm{Ni}_{4}(\mathrm{Hpha})_{2}(\mathrm{piv})_{6}(\mathrm{EtOH})_{2}\left(\mathrm{H}_{2} \mathrm{O}\right)_{2}\right](4)$.

$\mathrm{H}_{2}$ pha $1.5 \mathrm{H}_{2} \mathrm{O}(0.041 \mathrm{~g}, 0.25 \mathrm{mmol})$ was dissolved in $\mathrm{EtOH}(10 \mathrm{~mL})$ followed by the addition of triethylamine $(0.072 \mathrm{~mL}, 0.5 \mathrm{mmol})$ and of a solution of $\left\{\mathrm{Ni}_{2}\right.$ piv $\}(0.237 \mathrm{~g}, 0.25 \mathrm{mmol})$ in dichloromethane $(5 \mathrm{~mL})$. The mixture was stirred overnight and the resulting green solution left to slowly evaporate at room temperature. After ten days green crystals of 4 were collected by filtration and dried in air. Yield: $0.101 \mathrm{~g}$ (62\% based on Ni). Elemental analysis (\%) calculated for $\mathrm{C}_{48} \mathrm{H}_{82} \mathrm{~N}_{2} \mathrm{Ni}_{4} \mathrm{O}_{20}\left(\mathrm{M}_{\mathrm{r}}=1241.9 \mathrm{~g} \mathrm{~mol}^{-1}\right): \mathrm{C}, 46.4 ; \mathrm{H}, 6.6 ; \mathrm{N}, 2.2 ; \mathrm{Ni}, 18.9$. Found: C, 46.3; H, 6.7; N, 2.4; Ni, 18.8. ATR/FT-IR $\left(\mathrm{cm}^{-1}\right)$ : 3442w; 2956m; 2929w; 2902w; 2869w; 1603s; 1569w; $1539 \mathrm{w} ; 1523 \mathrm{w} ; 1482 \mathrm{~s} ; 1485 \mathrm{w}$; 1417s; 1372w; 1362m; 1324w; 1225s; 1207sh; 1156m; 1090m; 1051m; 1026w; 916w; 893w; 801sh; 787m; 708w; 687w; 607m; 561w; 495m; 419m; 399w.

$\left[\mathrm{Co}_{6}(\mathrm{Hpha})_{4}(\mathrm{piv})_{8}(\mathrm{EtOH})_{2}\right] \cdot \mathrm{EtOH}(5)$. 
$\mathrm{H}_{2}$ pha $1.5 \mathrm{H}_{2} \mathrm{O}(0.041 \mathrm{~g}, 0.25 \mathrm{mmol})$ was dissolved in $\mathrm{EtOH}(10 \mathrm{~mL})$ followed by the addition of triethylamine $(0.072 \mathrm{~mL}, 0.5 \mathrm{mmol})$ and of a solution of \{Co $2 \mathrm{piv}\}(0.237 \mathrm{~g}, 0.25 \mathrm{mmol})$ in dichloromethane $(5 \mathrm{~mL})$. The mixture was stirred overnight and the resulting purple solution left to slowly evaporate at room temperature. After six days pink crystals of 5 were collected by filtration and dried in air. Yield: $0.095 \mathrm{~g}$ (69\% based on Co). Elemental analysis (\%) calculated for $\mathrm{C}_{74} \mathrm{H}_{114} \mathrm{Co}_{6} \mathrm{~N}_{4} \mathrm{O}_{27}\left(\mathrm{M}_{\mathrm{r}}=1845.3 \mathrm{~g} \mathrm{~mol}^{-1}\right): \mathrm{C}, 48.1 ; \mathrm{H}, 6.2 ; \mathrm{N}, 3.0 ; \mathrm{Co}, 19.1$. Found: $\mathrm{C}$, 47.8; H, 6.3; N, 2.9; Co, 18.9. ATR/FT-IR $\left(\mathrm{cm}^{-1}\right): 3353 \mathrm{w} ; 3261 \mathrm{br} ; 2963 \mathrm{~m} ; 2929 \mathrm{w} ; 2901 \mathrm{w} ; 2871 \mathrm{w} ; 1623 \mathrm{sh} ; 1613 \mathrm{~s}$; 1573s; 1523w; 1481s; 1458w; 1418s; 1374m; 1359m; 1319w; 1226s; 1154s; 1091w; 1043w; 1025w; 912s; $888 w ; 787 s ; 707 s h ; 685 s ; 595 w ; 494 w ; 422 m ; 387 w$.

Physical measurements

Crystallographic data were collected on a Bruker Kappa-APEX II CCD diffractometer for 1, 2, 3 and 5 (Mокı, I = 0.71069 Å). Crystals were mounted on a Hamilton cryoloop using Paratone-N oil and placed in the cold flow produced with an Oxford Cryocooling device. Partial hemispheres of data -preselected with the APEX 2 software ${ }^{21}$ - were collected using $\varphi$ and $\omega$ scans (25 s/frame for 1-2 $40 \mathrm{~s} /$ frame for 3 and 5). Integrated intensities were obtained with SAINT and were corrected for absorption with SADABS. ${ }^{22}$ The structures were solved by direct methods and completed by iterative cycles of $\Delta \mathrm{F}$ syntheses and full-matrix least-squares refinement against $F^{2}$ using SHELXL software. ${ }^{21}$ Crystallographic data and refinements parameters for 1-3 and 5 are given in Table 1. Crystallographic details are available in CIF format. ${ }^{\ddagger}$ CCDC numbers 915714-915717.

The X-ray powder diffraction diagram of 4 was collected on a Philips X'pert Pro diffractometer using CuKa1 monochromatised radiation $(\lambda=1.54060 \AA)$ and equipped with a Pixcel detector. The comparison of the experimental powder pattern of 4 with the calculated one for 3 shows that the compounds are isostructural (Figure S1, ESI).

Magnetic measurements in dc mode were performed on a Quantum Design MPMS SOUID on a crushed crystalline sample restrained in a plastic film, drops of Paratone-N oil were added to prevent torquing of the crystallites. Data were corrected for the diamagnetism contributions of the samples using Pascal constants. The sample holder and Paratone-N oil diamagnetism were measured and subtracted from the raw data. To model the magnetic properties we used a homemade Mathematica code which establishes the hamiltonian matrix and calculates the partition function allowing the derivation of the physical properties. The best parameters were found using the Neldear-Mead algorithm. ${ }^{23}$

${ }^{1} \mathrm{H}$ and ${ }^{13} \mathrm{C}$ NMR spectra were collected on a $400 \mathrm{MHz}$ Bruker Avance spectrometer at $298 \mathrm{~K}$.

ATR/FT-IR spectra were collected on a Bruker TENSOR 27 equipped with a simple reflexion ATR diamond plate of the Harrick MPV2 series.

\section{Results and discussion}

Structures and synthesis

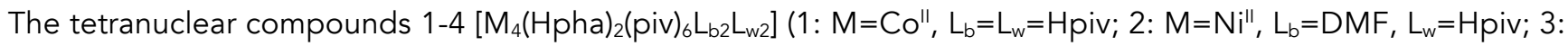
$\mathrm{M}=\mathrm{Co}$ "l, $\mathrm{L}_{b}=\mathrm{EtOH}, \mathrm{L}_{w}=\mathrm{H}_{2} \mathrm{O} ; 4: \mathrm{M}=\mathrm{Ni}^{\prime \prime}, \mathrm{L}_{b}=\mathrm{EtOH}, \mathrm{L}_{w}=\mathrm{H}_{2} \mathrm{O}$ ) are structurally closely related and all adopt a centrosymetric butterfly topology with two edge-sharing $\left\{\mathrm{MO}_{6}\right\}$ octahedra constituting the butterfly's body positions and two $\left\{\mathrm{MO}_{6}\right\}$ octahedra defining the wingtip positions, each connected to the body via a vertex (Figure 1a).

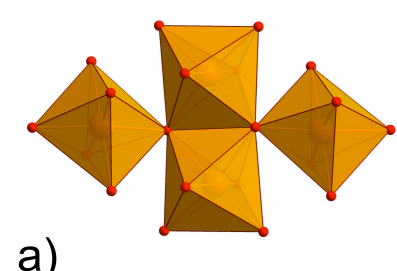

b)

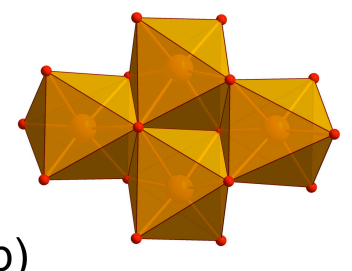

Fig. 1 Polyhedra representation of the butterfly topologies: a) $\left\{M_{4}\left(\mu_{3}-O\right)_{2}\right\}$ and b) $\left\{M_{4}\left(\mu_{3}-O\right)_{2}(\mu-O, N, X)_{4}\right\}$. 
In each cluster, two (Hpha)- ligands and six pivalate groups are found bridging the metal ions. The two body sites $(M(2)$ and $M(2) \#)$ are bridged to one wingtip position $(M(1))$ by a $m_{3}$-oxygen atom from the hydroxamate group and $\mathrm{M}(1)$ and $\mathrm{M}(2)$ are further bridged by one or two pivalate ligands alternatively (Figure 2). The oxygen atom from the carbonyl group of the phenylhydroxamate ligand binds $M(1)$. In 1 the coordination spheres of the cobalt ions are completed by pivalic acid both on the body and wingtip positions $\left(L_{b}=L_{w}\right)$ where in 2, DMF and pivalic acid molecules are found on the body and wingtip nickel ions, respectively.

In the isostructural compounds 3 and 4 ethanol act as terminal ligand for the metal ions located on the body positions and water is found on the wingtip metal centres. In compounds 1 to 4 the metal ions are all sixcoordinate with distorted octahedral geometries. Charge balance considerations, elemental analysis and BVS calculations support the presence of cobalt(II) ions in 1 and 3 . There are numerous butterfly-type clusters described in the literature although only one example is known with hydroxamate as a constitutive ligand. ${ }^{24}$ Yet the coordination mode of the ligand differs from the mode observed here with a $m$ hydroxamate oxygen atom instead of the $\mathrm{m}_{3}$ binding mode seen in compounds 1 to 4 . Regarding cobalt(II) and nickel(II) butterflies clusters, distinguishing $\left\{M_{4}\left(\mu_{3}-O\right)_{2}\right\}$ from $\left\{M_{4}\left(\mu_{3}-O\right)_{2}(\mu-O, N, X)_{4}\right\}$ (Figure 1) one can notice that the former structural type-to which 1 to 4 belong-is less common and almost systematically obtained in the presence of bridging carboxylate ligands. ${ }^{25,26,27,28}$ There are no clear signs of intermolecular interactions in the crystal packing of 1 and 2 however the presence of water molecules as terminal ligands in 3 and 4 leads to intermolecular $\mathrm{H}$-bonds with pivalate and hydroxamate oxygen atoms from adjacent clusters $(\mathrm{O}(-\mathrm{H}) \cdot \cdot \mathrm{O}$ distances of 2.72 and $2.88 \AA$ ) resulting in the formation of chains in the solid (Figure S2, ESI). 

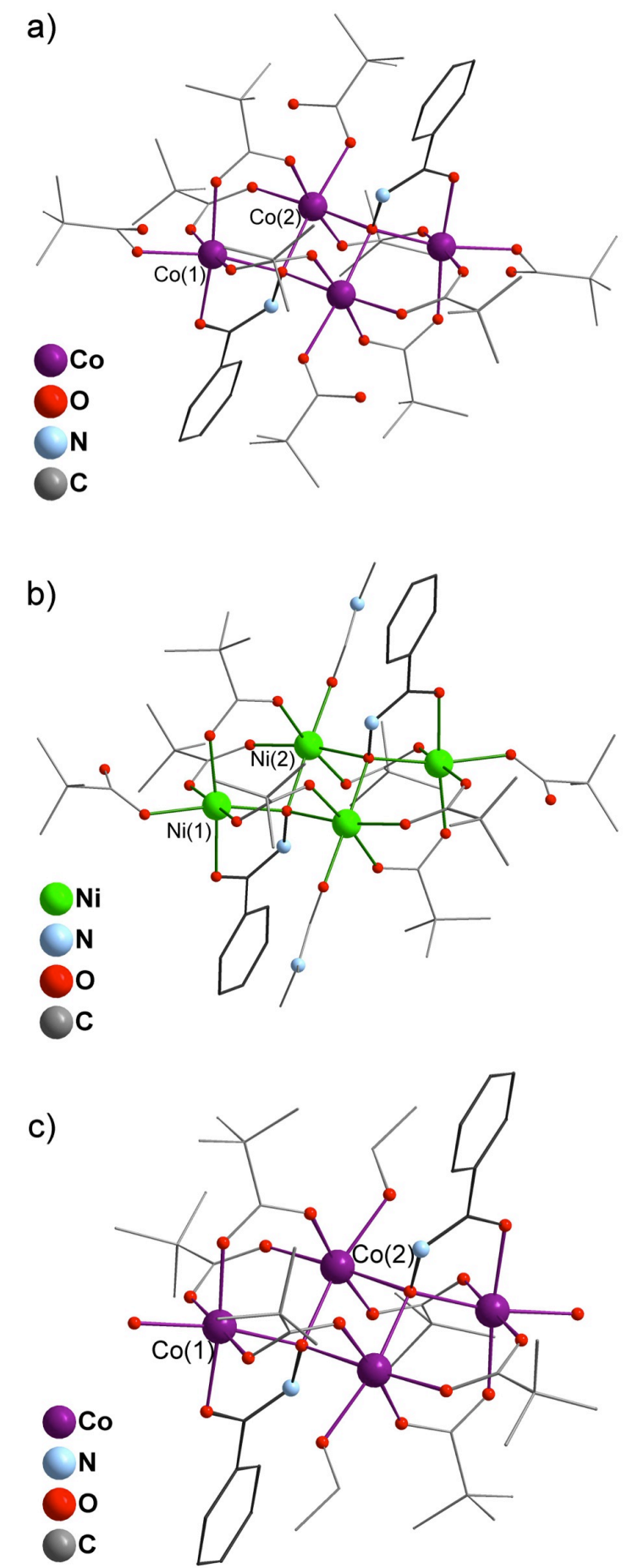

Fig. 2 Structure representations of a) 1, b) 2 and c) 3. $\mathrm{H}$ atoms have been omitted for clarity and (Hpha)- ligands represented in black.

Compound 5 is a hexametallic cluster made of four bridging hydroxamate ligands and eight bridging pivalate groups. The inorganic skeleton can be described as a butterfly with two additional cobalt centres extending the butterfly wings, formally resulting in the oxo-cluster $\left\{\mathrm{CO}_{6}\left(\mu_{3}-\mathrm{O}\right)_{4}(\mathrm{~m}-\mathrm{O})_{2}\right\}$ (Figure 3 ). 


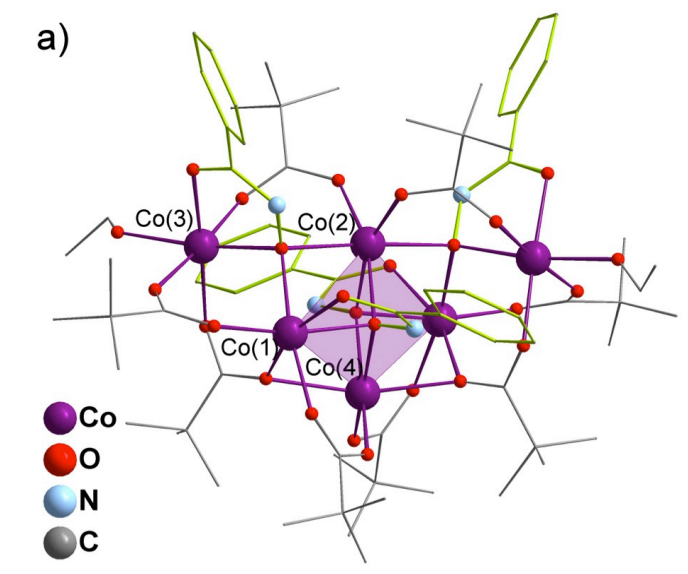

b)

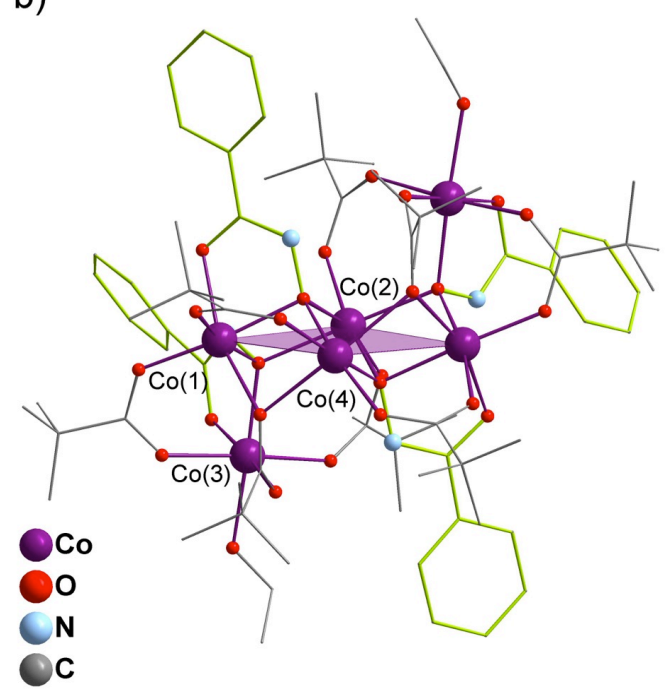

Fig. 3 Structure representations of 5, a) top view and b) side view. $\mathrm{H}$ atoms have been omitted for clarity and (Hpha) - ligands highlighted in lime.

The core butterfly is defined by $\mathrm{Co}(2)$ and $\mathrm{Co}(4)$ on the body positions, $\mathrm{Co}(1)$ and its symmetry equivalent being located on the wingtips. The additional cobalt atoms (Co(3) and $\mathrm{Co}(3) \#)$ are attached to two adjacent edges of the butterfly and situated on each side of its metallic plane (Figure 3b). The four (Hpha) ligands have similar coordination modes all with $\mu_{3}$ hydroxamate oxygen atoms but with two distinct environments. One consist in bridging $\mathrm{Co}(1)$ with both $\mathrm{Co}(2)$ and $\mathrm{Co}(4)$ within the internal butterfly and the second has a $\mu_{3}$-oxo group binding the external cobalt atoms $\mathrm{Co}(3)$ to the butterfly's body- and wingtip-located metal ions $\mathrm{Co}(1)$ and $\mathrm{Co}(2)$. The connectivity within the cluster is further supported by two kinds of bridging pivalate groups. Six carboxylates adopt a $\mu: \eta^{1}: \eta^{1}$ coordination mode connecting $C_{0}(1)$ with $\mathrm{Co}(3), \mathrm{Co}_{(2)}$ with $\mathrm{Co}(3)$ and $\mathrm{Co}(1)$ with Co(4) (and symmetry equivalents respectively). The remaining two pivalate groups show a $\mu_{3}: \eta^{2}: \eta^{1}$ binding mode linking $\mathrm{Co}_{(3)}$ with $\mathrm{Co}(1)$ and $\mathrm{Co}(4)$ (and symmetry equivalents resp.). Oxygen atoms from the carbonyl function of the phenylhydroxamate ligands complete the coordination spheres of $\mathrm{Co}(1)$ and $\mathrm{Co}(3)$. The latter is also coordinated to a terminal ethanol molecule. All the cobalt ions in 5 are six-coordinate with distorted octahedral geometries. Charge balance considerations, elemental analysis and BVS calculations support cobalt ions in the +ll oxidation state. To the best of our knowledge the topology of 5 has never been encountered to date in early transition metal ions coordination clusters.

In analogy to the observations made by Winpenny et al. ${ }^{11}$ it is likely that the tetrametallic cluster observed for 1 to 4 results from the condensation of two dimeric sub-unit that occurs when substituting the bridging water molecule in the metal-pivalate starting material by the hydroxamato group, hence forming a $\mu_{3}$-oxo bridge. Similarly the substitution of the bridging water molecules in the cobalt(II) dimer by the hydroxamate ligands 
should be driving the condensation of the metal ions in 5, however arguing whether an intermediate cluster of lower nuclearity is involved in a multi-step self-assembly mechanism seems rather inappropriate with no further solution studies. Structurally all compounds display a $\mu_{3}$-hydroxamate ligand which is a striking feature since there are only a limited number of hydroxamate-based coordination compounds displaying such a bonding mode. ${ }^{29}$ This in turn would explain the relatively high nuclearity of the clusters described here. Indeed the phenylhydroxamate-based coordination clusters reported to date are dinuclear or trinuclear species with $\mathrm{m}$ hydroxamate oxygen atoms only. ${ }^{13,30}$ There is only one recent example of high nuclearity compound based on phenylhydroxamate displaying a $m_{3}$ oxygen atom, a $\left\{\mathrm{CO}_{16}\right\}$ cluster. ${ }^{13 \mathrm{~d}}$ This cluster was prepared solvothermally. Compounds 1 to 5 represent then some of the highest nuclearities obtained so far in the presence of phenylhydroxamic acid. However, the incomplete deprotonation of the ligand has most definitely restrained the nuclearity of the formed species. The synthesis of 1 when compared to 2-5 tends to indicate that in the absence of base proton exchange between the carboxylate groups and the hydroxamic acid is sufficient to generate the $\mathrm{m}_{3}$-hydroxamate bridge. A look at the synthesis of 4 and 5 shows that the addition of two equivalents of base per ligand does not lead to the formation of the hydroximate bridge but results, in the case of cobalt(II), in a slight increase of the hydroxamate to metal ratio.

\section{Magnetic properties}

DC magnetic susceptibility measurements were performed for 1 to 5 at $1 \mathrm{kOe}$ in the 2-300 $\mathrm{K}$ temperature range (Figure 4). At $300 \mathrm{~K}, \mathrm{C}_{\mathrm{M}}$ T values for 1 and 3 are equal to $13.1 \mathrm{~cm}^{3} \mathrm{Kmol}^{-1}$ and $12.7 \mathrm{~cm}^{3} \mathrm{Kmol}^{-1}$, values compatible with the expected ones for four non-interacting cobalt(II) ions. ${ }^{32}$ Upon cooling, the $\chi_{M}$ T products steadily decrease to reach values of $0.6 \mathrm{~cm}^{3} \mathrm{Kmol}^{-1}$ and $0.44 \mathrm{~cm}^{3} \mathrm{Kmol}^{-1}$ at $2.5 \mathrm{~K}$. At $300 \mathrm{~K}, 5$ has a $\chi_{\mathrm{M}}$ T value of $20.6 \mathrm{~cm}^{3} \mathrm{Kmol}^{-1}$ which is in agreement with the expected one for six non-interacting cobalt(II) ions. ${ }^{32}$
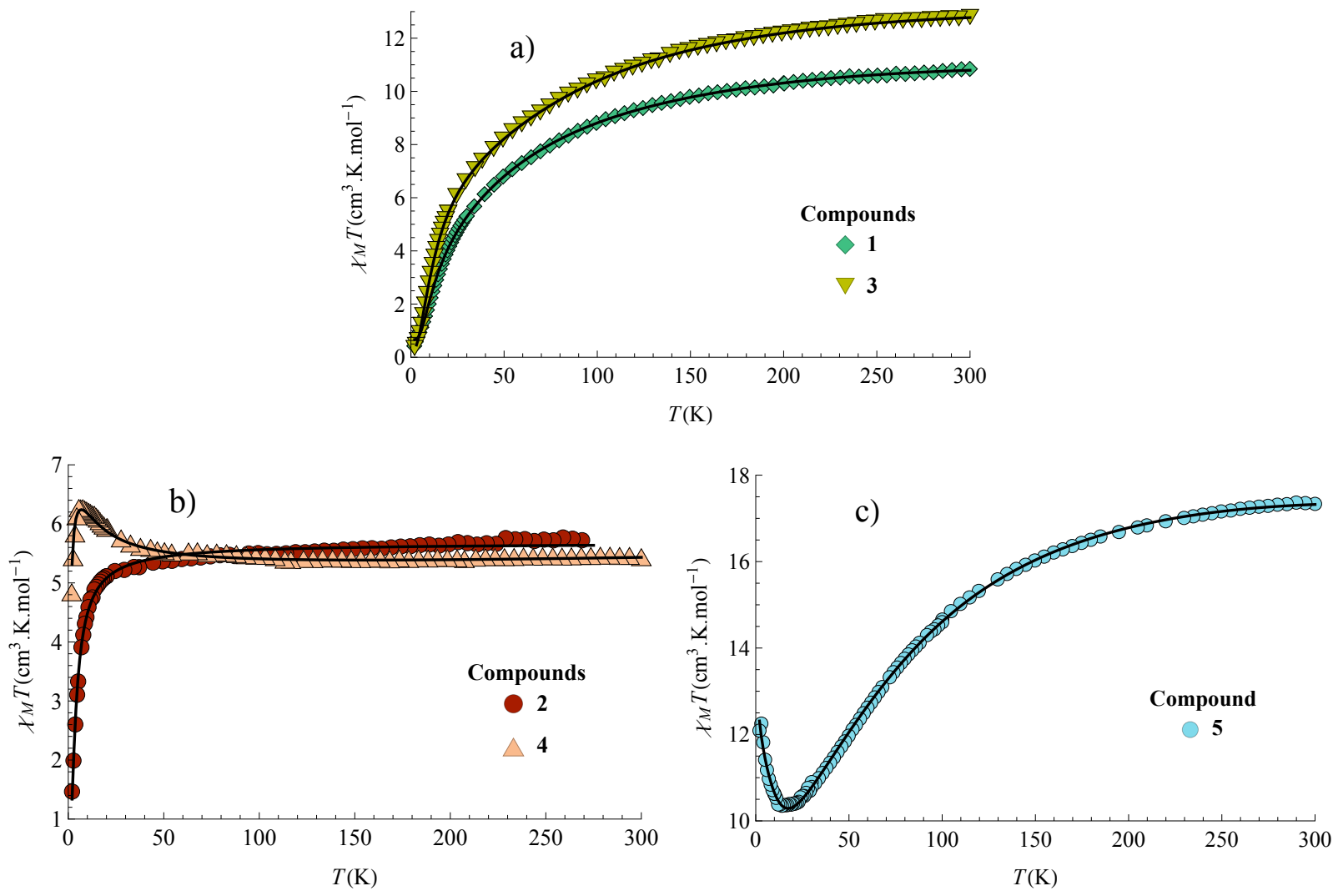


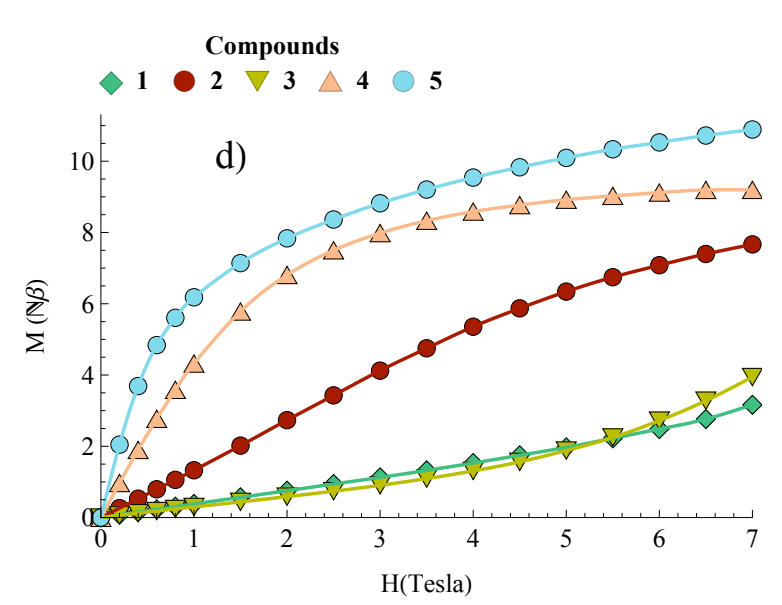

Fig. 4 a-c) Plots of $c_{M} T$ vs. T measured from 300 to $2 \mathrm{~K}$ at $1 \mathrm{kOe}$ for $1(\diamond), 2(\bullet), 3(\nabla), 4(\Delta)$ and $5(0)$, the solid black lines are the best-fit curves; d) plots of $\mathrm{M}$ vs. $\mathrm{H}$ measured from 0 to $7 \mathrm{~T}$ at $2 \mathrm{~K}$ for $1(\diamond), 2(\bullet), 3(\nabla)$, $4(\triangle)$ and $5(0)$, the solid lines are a guide for the eyes.

The product continuously decreases when lowering the temperature, reaches a minimum of $10.4 \mathrm{~cm}^{3} \mathrm{Kmol}^{-1}$ at ca. $16 \mathrm{~K}$ then increases to a local maximum of $12.25 \mathrm{~cm}^{3} \mathrm{Kmol}^{-1}$ at $3 \mathrm{~K}$ and finally drops to $12.1 \mathrm{~cm}^{3} \mathrm{~K} . \mathrm{mol}^{-1}$ at 2 $\mathrm{K}$. Besides spin-orbit coupling, the rise of $\chi_{M} T$ at low temperature for 5 tends to indicate the co-existence within the cluster of antiferro- and ferromagnetic interactions. At room temperature the $\chi_{M} T$ values for 2 and 4 are equal to 5.8 and $5.43 \mathrm{~cm}^{3} \mathrm{Kmol}^{-1}$ respectively and are relatively higher than the expected value for four noninteracting nickel(II) ions $\left(4.8 \mathrm{~cm}^{3} \mathrm{Kmol}^{-1}\right.$, assuming $\left.\mathrm{g}=2.2\right)$. The $\chi_{M} T$ product for 2 is almost constant from 300 to $22 \mathrm{~K}$ and then rapidly falls close to zero at $2 \mathrm{~K}$. This behaviour would be consistent with weak antiferromagnetic interactions along with zero-field splitting. The $\chi_{M} T$ curve for 4 shows no significant variation down to $100 \mathrm{~K}$, slowly increases to $6.3 \mathrm{~cm}^{3} \mathrm{Kmol}^{-1}$ at $6 \mathrm{~K}$ and then drops to 5.3 at $2 \mathrm{~K}$, which indicates weak ferromagnetic coupling as well as zero-field splitting.

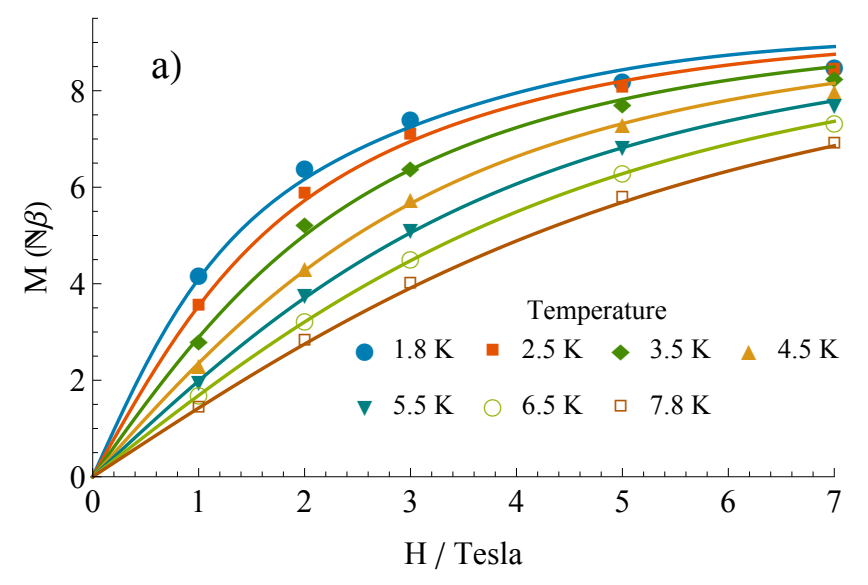




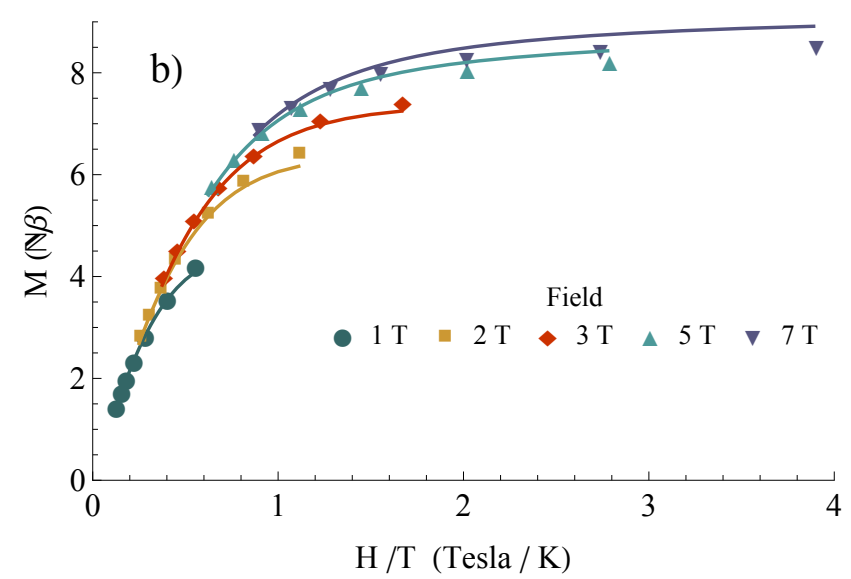

Fig. 5 a) $\mathrm{M}$ vs. $\mathrm{H}$ measured from 0 to $7 \mathrm{~T}$ and $1.8 \mathrm{~K}$ to $7.8 \mathrm{~K}$ for 4 ; b) Isofield $\mathrm{M}$ vs $\mathrm{H} / \mathrm{T}$ from $1 \mathrm{~T}$ to $7 \mathrm{~T}$ for 4 , the solid lines are the best-fit curves.

The magnetisation curves measured at $2 \mathrm{~K}$ support the observations made from the $\chi_{M} T$ vs. T plots. For 1,2 and 3 , the $M$ vs. $H$ curves tend to confirm the existence of moderate to weak antiferromagnetic exchange interactions and no signs of saturation are observed at $7 \mathrm{~T}$ (Figure $4 \mathrm{~d}$ ). The magnetisation curve of 4 saturates at $8.5 \mathrm{Nm}_{\mathrm{B}}$ which would confirm the existence of ferromagnetic interactions leading to an $\mathrm{S}=4$ ground state. For $4 \mathrm{M}$ vs. $\mathrm{H}$ at various temperature and isofield data have also been measured between 0 and $7 \mathrm{~T}$ and between $1.8 \mathrm{~K}$ and $8 \mathrm{~K}$ (Figure 5). The separation of the isofield curves indicates the presence of zero field splitting or (and) the existence of populated low lying excited states. At $7 \mathrm{~T}$, the magnetisation of 5 reaches 11 $\mathrm{Nb}$ but no saturation is observed which is coherent with the presence of anisotropic cobalt(II) ions.

Since the pioneering work of Lines, ${ }^{31}$ modelling the magnetic properties of high-spin Co(II) polynuclear complexes is still an open challenge due to the presence of unquenched orbital angular momentum and several approaches have been proposed. ${ }^{32}$ In the cobalt butterfly compounds 1 and 3 there are two different pathways between the cobalt ions of the wing and the two cobalt ions of the body. To limit overparametrisation only one wing-body interaction has been considered according to scheme 1 (a).

(a)

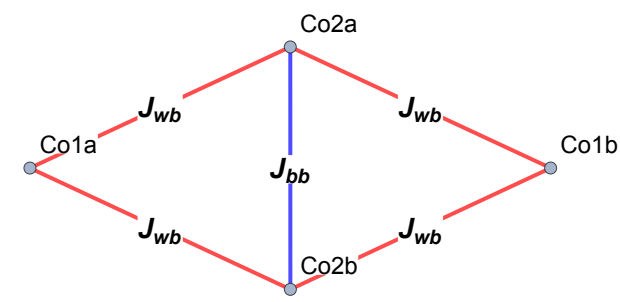

(b)

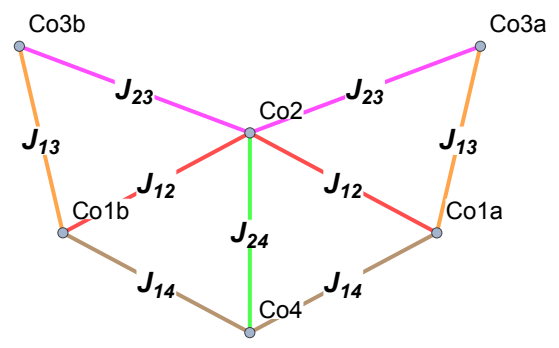

Scheme 1: Topology of interaction in 1 and 3 (a) and in 5 (b) 
In this context, the appropriate Hamiltonian to model the magnetic properties of 1 and 3 is: $\mathcal{H}_{\text {tot }}=\mathcal{H}_{\text {int }}+$ $\mathcal{H}_{\text {so }}+\mathcal{H}_{\text {Ze }}$ with

$\mathcal{H}_{\text {int }}=-J_{b b} S_{C o 2 a} \cdot S_{C o 2 b}$

$-J_{w b}\left(S_{C 01 a} \cdot S_{C o 2 a}+S_{C o 1 a} \cdot S_{C o 2 b}+S_{C o 1 b} \cdot S_{C o 2 a}+S_{C o 1 b} \cdot S_{C o 2 b}\right)$

$\mathcal{H}_{s o}^{v}=\sum_{i=1}^{4}-\frac{3}{2} \alpha \lambda L_{C o i} S_{C o i}$

$\mathcal{H}_{Z e}=\sum_{i=1}^{4}\left[\Delta\left(L^{2}{ }_{Z C o i}-\frac{1}{3} L_{C o i}^{2}\right)+\left(-\frac{3 \alpha}{2} L_{v C o i}+g_{e} S_{v C o i}\right) \beta . H\right]$

with $\mathrm{n}=\mathrm{x}, \mathrm{y}, \mathrm{z}$

and where $J_{\mathrm{bb}}$ is the coupling constant between the two cobalt ions in the butterfly body positions and $J_{w b}$ the coupling constant between the body and the wing cobalt ions. For the $\mathrm{H}_{\text {so }}$ Hamiltonian, $\mathrm{I}$ is the spin-orbit coupling constant, a the orbital reduction factor and $D$ the axial distortion parameter. $L$ et $S$ are respectively the orbital and spin operators with $L=1$ and $S=3 / 2$ in the T-P isomorphism approach ${ }^{33}$. To simplify, all the cobalt ions are assumed to be identical and the values of $a, I$ and $D$ are averaged values. However, even within this idealised model, the size of the matrix $(20736 \times 20736)$ is too large to have the problem treated exactly in a reasonable amount of time. To overcome this situation we used the pertubational approach developped by Lloret et $a^{32 b}$ where the $c_{M} T$ product is expressed has :

$\mathrm{C}_{M} T=\mathrm{F}_{\text {tetra }}\left[\mathrm{G}_{\mathrm{i}}\left(T, \mathrm{~J}_{\mathrm{ij}, \mathrm{l}} \mathrm{l}, \mathrm{a}, \mathrm{D}\right), \mathrm{T}, \mathrm{J}_{\mathrm{ij}}\right]$

where $F_{\text {tetra }}$ is the thermal variation of $\chi_{M} T$ calculated for a tetranuclear cluster with the same topology than 1 and 3 but with a fictitious $S_{\text {eff }}=1 / 2$ to mimic the ground state Kramer doublet of a Co(II) ion. To establish the $F_{\text {tetra }}$ analytical law it is necessary to take into account a $25 / 9$ scaling factor in the Heisenberg Hamiltonian $\mathrm{H}_{\text {int }}(\mathrm{S}$ $=>5 / 3 S_{\text {eff }}$ leading to the following Hamiltonian:

$\mathcal{H}_{\text {tot }}=\mathcal{H}_{\text {int }}+\mathcal{H}_{\text {Ze }}$

$\mathcal{H}_{\text {int }}=-\frac{25}{9} J_{b b} S_{\text {Co2a }}^{e f f} . S_{\text {Co2b }}^{e f f}$

$-\frac{25}{9} J_{w b}\left(S_{C o 1 a}^{e f f} \cdot S_{C o 2 a}^{e f f}+S_{C o 1 a}^{e f f} \cdot S_{C o 2 b}^{e f f}+S_{C o 1 b}^{e f f} \cdot s_{C o 2 a}^{e f f}+S_{C o 1 b}^{e f f} . S_{C o 2 b}^{e f f}\right)$

$\mathcal{H}_{Z E}=\sum_{i=1}^{4} G_{C o i}\left(T, J_{i j}\right) \beta S_{C o i}^{e f f} H$

In $F_{\text {tetra }}$ the Landé factors of $S_{\text {eff }}$ are replaced by the $G_{c_{0 i}}\left(T, J_{i j}, I, a, D\right)$ fictitious Landé factors introduced to take into account the influence of the excited states due to spin-orbit coupling and exchange interaction. These $\mathrm{G}_{\mathrm{coi}}$ factors are calculated according to

$G_{C o i}^{2}\left(T, J_{i j}, \lambda, \alpha, \Delta\right)=\frac{4 k}{N \beta^{2}}\left(\chi_{M} \cdot T\right)_{C o}+f\left(J_{i j}, T\right)^{2}$.

$\left(\chi_{M} T\right)_{C_{0}}$ is the thermal variation of $C_{M} T_{i}$ for an isolated anisotropic cobalt ion calculated by full diagonalisation of the hamiltonian matrix and $f\left(\mathrm{~J}_{\mathrm{ij}}, \mathrm{T}\right)$ is a pertubation term due to excited levels (see $\mathrm{SI}$ ).

It is extremely delicate to obtain reliable values for a model depending on five parameters. To avoid purely mathematical fits, at least 20 sets of starting parameters were used. All the optimisations lead to a dominant antiferromagnetic $J_{w b}$ interaction around $5 \mathrm{~cm}^{-1}$ but to a relatively wide range of $J_{b b}$ values. As $J_{w b}$ determines the magnetic behaviour of the compound and in fact creates an effective ferromagnetic interaction between the two Co(II) ions in the body positions, a reliable determination of the $J_{b b}$ value by magnetic measurements is difficult. Nevertheless, if for 1 the $J_{\mathrm{bb}}$ value does not have a great influence on the quality of the fit, there is an improvement by a factor 10 of the agreement factor for 3 when a ferromagnetic $J_{b b}$ is taken into account. It is noteworthy that the need of a ferromagnetic $\mathrm{J}_{\mathrm{bb}}$ interaction to model the magnetic properties of 3 is coherent with the ferromagnetic interaction observed in the isostructural $\mathrm{Ni}(\mathrm{II})$ compound 4 . The final fit for 1 is obtained setting $J_{b b}$ to zero and the least square fit of the magnetic data gave $J_{w b}=-4.8 \mathrm{~cm}^{-1}, I=-143 . \mathrm{cm}^{-1}, a=0.78$, $D=429 \mathrm{~cm}^{-1}$, with $R=3.110^{-5}$. The least square fit for 3 gave $J_{w b}=-3.7 \mathrm{~cm}^{-1}, J_{b b}=6.2 \mathrm{~cm}^{-1}, I=-152 . \mathrm{cm}^{-1}, a=$ $0.99, D=466 \mathrm{~cm}^{-1}$, with $R=6.410^{-6}$ for 3 . Almost equivalent fits are obtained with negative $D$ values. The 
significant antiferromagnetic $J_{w b}$ interaction is not unexpected as the bridging angles $\mathrm{Co}(1)-\mathrm{O}(1)-\mathrm{Co}(2)$ between the $\mathrm{Co}(\mathrm{II})$ ions of the body and the $\mathrm{Co}$ (II) ions of the wings are in the $108^{\circ}-120^{\circ}$ range leading to an overlap between the magnetic orbitals. On the other hands, the angles $\mathrm{Co}(2)-\mathrm{O}(1)-\mathrm{Co}(2)$ between the body ions are equal to $99^{\circ}$ and $97.4^{\circ}$ for 1 and 3 respectively. These values are close to the situation of accidental orthogonality of the magnetic orbitals and should lead to weak ferromagnetic $J_{b b}$ interactions or to $J_{b b}$ values close to zero since such angles also fall in the range where AF contribution can compensate the ferromagnetic one. The spin-orbit coupling constant $I$ is in a reasonable range for both compounds but the orbital reduction parameter a seems too high for 3 . However it is impossible to obtain a good fit with an a value smaller than 0.9 .

The appropriate Hamiltonian to model the magnetic properties of 5 is (scheme $1(b)$ ) : $\mathcal{H}_{\text {tot }}=\mathcal{H}_{\text {int }}+\mathcal{H}_{\text {so }}+\mathcal{H}_{\text {Ze }}$ with

$$
\begin{aligned}
& \mathcal{H}_{i n t}=-J_{12}\left(S_{C o 1 a} \cdot S_{C o 2}+S_{C o 1 b} \cdot S_{C o 2}\right) \\
& -J_{13}\left(S_{C o 1 a} \cdot S_{C o 3 a}+S_{C o 1 b} . S_{C o 3 b}\right) \\
& -J_{14}\left(S_{C o 1 a} \cdot S_{C o 4}+S_{C o 1 b} \cdot S_{C o 4}\right) \\
& -J_{23}\left(S_{C o 2} \cdot S_{C o 3 a}+S_{C o 2} \cdot S_{C o 3 b}\right)-J_{24} S_{C o 2} \cdot S_{C o 4} \\
& \mathcal{H}_{s o}^{v}=\sum_{i=1}^{6}-\frac{3}{2} \alpha \lambda L_{C o i} S_{C o i} \\
& \mathcal{H}_{Z e}=\sum_{i=1}^{6}\left[\Delta\left(L_{Z C o i}-\frac{1}{3} L_{C o i}^{2}\right)+\left(-\frac{3 \alpha}{2} L_{v C o i}+g_{e} S_{v C o i}\right) \beta . H\right]
\end{aligned}
$$

Where $\mathrm{J}_{\mathrm{ij}}$ are the coupling constants, the other symbols have the same meaning than in the previous formula. As for 1 and 3, overparametrisation is minimised assuming that all the cobalt ions are identical and thus that the values of $a, I$ and D are averaged values. Nevertheless, due to the size of the hamiltonian matrix (2 985984 x 2985 984) it is almost impossible to fit the magnetic data using this model and as for the butterfly compounds we used the pertubational approach developped by Lloret et alErreur! Signet non défini. where the $\chi_{M} T$ product is expressed has:

$\chi_{M} T=F_{h e x a}\left[G_{i}\left(T, J_{i j}, I, a, D,\right), T, J_{i j}\right]$

where $F_{\text {hexa }}$ is the thermal variation of $\mathrm{C}_{M} T$ for an hexanuclear cluster with the same topology than 5 but with an effective spin $S^{\text {eff }}=1 / 2$ to mimic the ground state Kramer doublet of a Co(II) ion. For 5 , it is not possible to derive an analytical law for the $S=1 / 2$ hexanuclear complex and the thermal variation of $\chi_{M} T$ is obtained by full diagonalisation of the hamiltonian matrix established with the following hamiltonian. $\boldsymbol{H}_{\text {tot }}=\mathcal{H}_{\text {int }}+\mathcal{H}_{\boldsymbol{Z} \boldsymbol{e}}$

$$
\begin{aligned}
& \mathcal{H}_{\text {int }}=-\frac{25}{9} J_{12}\left(S_{C o 1 a}^{e f f} s_{C o 2}^{e f f}+S_{C o 1 b}^{e f f}, s_{C o 2}^{e f f}\right) \\
& -\frac{25}{9} J_{13}\left(s_{C o 1 a}^{e f f} s_{C o 3 a}^{e f f}+s_{C o 1 b}^{e f f} s_{C o 3 b}^{e f f}\right) \\
& -\frac{25}{9} J_{14}\left(s_{C o 1 a}^{e f f} s_{C o 4}^{e f f}+S_{C o 1 b}^{e f f} S_{C o 4}^{e f f}\right) \\
& -\frac{25}{9} J_{23}\left(s_{C o 2}^{e f f} S_{C o 3 a}^{e f f}+S_{C o 2}^{e f f} S_{C o 3 b}^{e f f}\right)-\frac{25}{9} J_{24} S_{C o 2}^{e f f} s_{C o 4}^{e f f} \\
& \mathcal{H}_{Z e}=\sum_{i=1}^{6} G_{C o i}\left(T, J_{i j}\right) \beta S_{C o i}^{e f f} H
\end{aligned}
$$

The mathematical form of the $\mathrm{G}_{\mathrm{coi}}\left(T, \mathrm{~J}_{\mathrm{ij}}\right)$ factors for 5 are given in supplementaty informations.

In a first attempt and to limit overparametrisation we fixed $I$ and a to sensible values $\left(I=-160 \mathrm{~cm}^{-1}\right.$ and $a=$ 0.85 ) and find the best values for the other parameters. After this first step we blocked the $\mathrm{J}_{\mathrm{ij}}$ and $\Delta$ parameters to their best values and optimised the $\lambda$ and $\alpha$ parameters. In an iterative way we repeated these two steps procedure several times until the process converges to stable values. The best fit curve shown in figure $4 \mathrm{c}$ is obtained for $J_{12}=-1.3 \mathrm{~cm}^{-1}, J_{13}=-0.28 \mathrm{~cm}^{-1}, J_{14}=5.9 \mathrm{~cm}^{-1}, J_{23}=-9.8 \mathrm{~cm}^{-1}, J_{24}=-0.19 \mathrm{~cm}-1$ and $\mathrm{D}=348 . \mathrm{cm}^{-1}$, $\mathrm{I}=-159 \mathrm{~cm}^{-1}$ and $\mathrm{a}=0.84$.

The magnetic behaviour of 5 is determined by two main interactions: $J_{14}$ and $J_{23}$. The existence of one 
ferromagnetic interaction, $J_{14}$, was expected and is consistent with the rise of $c_{M} T$ below $16 \mathrm{~K}$. Magnetically, this polynuclear complex is made up of two weakly coupled trinuclear parts. The first part is comprised of the $\mathrm{Co}(2)$ ion and the two $\mathrm{Co}(3)$ ions. In this trimetallic entity a large antiferromagnetic interaction is expected between $\mathrm{Co}(2)$ and the $\mathrm{Co}(3)$ ions due to a large $\mathrm{Co}(2)-\mathrm{O}(1)-\mathrm{Co}(3)$ angle of $120^{\circ}$ which allows a very good overlap between the magnetic orbitals. The second part is composed by the Co(4) ion and the two Co(1) ions. The modelling gives a ferromagnetic interaction between $\mathrm{Co}(4)$ and the $\mathrm{Co}(1)$ ions. This is not unexpected since the values of the bridging angles between $\mathrm{Co}(1)$ and $\mathrm{Co}(4)$ are equal to $90.1^{\circ}$ for $\mathrm{Co}(1)-\mathrm{O}(9)-\mathrm{Co}(4)$ and 95. $5^{\circ}$ for $\mathrm{Co}(1)-\mathrm{O}(5)-\mathrm{Co}(4)$. These angles are close $90^{\circ}$ and lead to accidental orthogonality of the magnetic orbitals and consequently give ferromagnetic interaction between the $\mathrm{Co}(\mathrm{II})$ ions. The weak values of $J_{12}$ and $J_{13}$ are more difficult to explain, but for $J_{12}$ the two bridging angles $\mathrm{Co}(1)-\mathrm{O}(1)-\mathrm{Co}(2)$ and $\mathrm{Co}(1)-\mathrm{O}(5)-\mathrm{Co}(2)$ are equal to $99.3^{\circ}$ and $103.3^{\circ}$ respectively and these values are probably not sufficiently large to give an ample overlap between the magnetic orbitals. For $\mathrm{J}_{13}$ the bridging angle $\mathrm{Co}(1)-\mathrm{O}(1)-\mathrm{Co}(3)$ is equal to $109^{\circ}$ and relatively large antiferromagnetic interaction is expected. However, these two ions are also bridged by two carboxylate groups and it is well established that such bridges can drastically reduce the antiferromagnetic interaction due to countercomplementarity effects. ${ }^{34}$

With the lack of first order spin-orbit coupling the two Ni(II) complexes 2 and 4 are easier to model. The Hamiltonian for 2 is the following:

$\mathcal{H}=-J_{b b} S_{N i 2 a} \cdot S_{N i 2 b}-J_{w b 1}\left(S_{N i 2 a} \cdot S_{N i 1 a}+S_{N i 2 b} \cdot S_{N i 1 b}\right)$

$-J_{w b 2}\left(S_{N i 2 a} \cdot S_{N i 1 b}+S_{N i 2 b} \cdot S_{N i 1 a}\right)+g_{N i} \beta H\left(S_{N i 2 a}+S_{N i 2 b}+S_{N i 1 a}+S_{N i 1 b}\right)$

where $J_{b b}$ is the body-body interaction and $J_{w b 1}$ and $J_{w b 2}$ are the two different wing-body interactions. To simplify we have in this Hamiltonian taken the same isotropic $\mathrm{g}_{\mathrm{Ni}}$ factor in the Zeeman term for all the $\mathrm{Ni}$ (II) ions. To avoid overparametrisation we have set $J_{\mathrm{wb} 1}=J_{\mathrm{wb} 2}=J_{\mathrm{wb}}$ and the least square fit of the magnetic data gave $J_{b b}=0.96 \mathrm{~cm}^{-1}, J_{w b}=-1.3 \mathrm{~cm}^{-1}$ and $g_{N i}=2.38$ with $R=1.6 .10^{-4}$. An almost equivalent fit is obtained setting $J_{b b}$ to zero $\left(J_{w b}=-1.28 \mathrm{~cm}^{-1}, g_{N i}=2.38 R=2.1 .10^{-4}\right)$ showing that as for compounds 1 and 3 the $J_{w b}$ governs the magnetic behaviour of 2 and that $\mathrm{J}_{\mathrm{bb}}$ is weak or null. It is worthy of note that, as in the cobalt butterfly complexes, in spite of the large $\mathrm{Ni}(1)-\mathrm{O}(1)-\mathrm{Ni}(2)$ angles $\left(111^{\circ}\right.$ and $\left.121^{\circ}\right)$ the antiferromagnetic $\mathrm{J}_{\text {wb value }}$ is weak. This is most probably due to the non planar conformation of the butterfly structure and also to the presence of carboxylate bridges which could bring a countercomplementarity effect. ${ }^{34}$

The experimental evidence of a magnetic ground state and the strong likelihood of anisotropy in 4 lead us to add a ZFS term in the Hamiltonian to model the magnetic data. Indeed attempts to fit the magnetisation data by taking into account only exchange interactions without ZFS parameter failed. The anisotropy and Landé factors of all the nickel ions are assumed to be identical and the $D_{\mathrm{Ni}}$ and $g_{\mathrm{Ni}}$ values are averaged values. To limit overparametrisation we also set $J_{w b 1}=J_{w b 2}=J_{w b}$ and take isotropic g $g_{N i}$ Landé factor. In this approximation, the appropriate Hamiltonian for compound 4 is:

$\mathcal{H}=-J_{b b} S_{N i 2 a} \cdot S_{N i 2 b}-J_{w b}\left(S_{N i 2 a} \cdot S_{N i 1 a}+S_{N i 2 b} \cdot S_{N i 1 b}+S_{N i 2 a} \cdot S_{N i 1 b}+S_{N i 2 b} \cdot S_{N i 1 a}\right)$

$+\sum_{j=1}^{4} D_{N i}\left(S_{N i(j) z}^{2}-2 / 3\right)+g_{N i} \beta H\left(S_{N i 2 a}+S_{N i 2 b}+S_{N i 1 a}+S_{N i 1 b}\right)$

Since only low temperature data give information on the ZFS in the $C_{M} T$ plot we simultaneously fitted the $\chi_{M} T$ and isofield data to get a more reliable value for $\mathrm{D}_{\mathrm{Ni}}{ }^{35}$ The least square fit of both set of data gives $\mathrm{J}_{\mathrm{bb}}=7.0$ $\mathrm{cm}^{-1}, J_{\mathrm{wb}}=0 \mathrm{~cm}^{-1}, \mathrm{D}_{\mathrm{Ni}}=3.2 \mathrm{~cm}^{-1}, \mathrm{~g}=2.27$, with $\mathrm{R}=1.810^{-4}$. The ferromagnetic interaction between the $\mathrm{Ni}(\mathrm{II})$ ions in 4 is not surprising, this compound is isostructural to 3 and the bridging angle $\mathrm{Ni}(2)-\mathrm{O}(1)-\mathrm{Ni}(2)$ between the body ions should be close to $97^{\circ}$, a value in the range of the expected ones to observe a ferromagnetic interaction between $\mathrm{Ni}(\mathrm{II})$ ions. ${ }^{36}$ By contrast, in 2 the bridging angle $\mathrm{Ni}(2)-\mathrm{O}(1)-\mathrm{Ni}(2)$ is larger and it is equal to 99.6: in the probable range where the weak antiferromagnetic contribution due to the overlap of the magnetic orbitals compensates the ferromagnetic contribution due to exchange integrals leading to a very weak or null value for $\mathrm{Jbb}_{\mathrm{bb}}$. The null value of the wing-body interactions is more puzzling but this interaction is already quite small in 2 and is also probably due to the non-planar conformation of the butterfly structure and also to the possible existence of countercomplementarity effects due to the presence of carboxylate bridges. ${ }^{34}$ 


\section{Conclusions}

This preliminary study shows great potential in the strategic use of pre-formed coordination clusters to react with hydroxamate ligands since it has led to five new coordination clusters. The use of ortho-substituted phenylhydroxamic acid to favour the formation of hydroximate bridges or else the use of polyhydroxamic acid should lead to higher nuclearity clusters. It would also be relevant to study the reactivity of the phenyhydroxamic acid towards coordination clusters of different shape and/or nuclearity. These new synthetic routes are currently explored in our group. The magnetic properties of the clusters described in this paper are less exciting than expected. Indeed none of the compounds show slow relaxation of the magnetisation at low temperature. Yet compounds 4 and 5 present magnetic ground states with some ferromagnetic interactions hinting at the possible preparation of SMMs following the synthetic strategy described here. We also would like to emphasize that it is possible to obtain a satisfactory model of the magnetic properties of coordination clusters containing metal ions with unquenched orbital angular momentum in spite of the overparametrisation risk. However obtaining reliable results requires caution. It can be fulfilled with a robust optimisation method, multiple tries using several sets of starting parameters and common sense, of course.

\section{Acknowledgements}

This work was supported by the Ministère de la Recherche et de I'Enseignement Supérieur (MRES) and the Centre National de la Recherche Scientifique (CNRS).

\section{Notes and references}

a Sorbonne Universités, UPMC Univ Paris 06, UMR 8232, Institut Parisien de Chimie Moléculaire, ,F-75005 Paris, France. Fax: +331442738 41; Tel: +331442755 62; E-mail: yves.journaux@upmc.fr

b CNRS, UMR 8232, Institut Parisien de Chimie Moléculaire, F-75005 Paris, France

c Centre de résolution structurale, Institut Parisien de Chimie Moléculaire,'Paris, 75005, France

$\S$ Dedicated to Pr Marius Andruh in celebration of his 60th birthday

$\$$ These data can be obtained free of charge via http://www.ccdc.cam.ac.uk/cgi-bin/catreg.cgi (or from the Cambridge Crystallographic Data Centre, 12, Union Road, Cambridge CB2 1EZ, UK; fax: (+44) 1223-336-033; or deposit@ccdc.cam.ac.uk).

See themed issues on molecular magnets and molecule-based magnets: Dalton Trans., 2010, 39, 4653-5039 and Chem. Soc. Rev., 2011, 40, 30533368.

2 (a) D. Gatteschi, R. Sessoli and J. Villain, Molecular Nanomagnets, Oxford University Press, 2006; (b) R. E. P. Winpenny, and E. J. L. McInnes, Molecular Nanomagnets, in Molecular Materials (eds D. W. Bruce, D. O'Hare and R. I. Walton), John Wiley \& Sons, Ltd, Chichester, UK, 2010; (c) R. Lescouëzec, L. M. Toma, J. Vaissermann, M.Verdaguer, F. S. Delgado, C. Ruiz-Pérez, F. Lloret and M. Julve, Coor. Chem. Rev., 2005, 249, 26912729; (d) H. Miyasaka, M. Julve, M. Yamashita and R. Clérac, Inorg. Chem., 2009, 48, 3420-3437; (e) S. Ferlay, T. Mallah, R. Ouahès, P. Veillet and M. Verdaguer, Nature, 1995, 378, 701-703; (f) O. Sato, J. Tao and Y.-Z. Zhang, Angew. Chem. Int. Ed., 2007, 46, 2152-2187; (g) M. N. Leuenberger and D. Loss, Nature 2001, 410, 789-793; (h) F. Troiani, A. Ghirri, M. Affronte, S. Carretta, P. Santini, G. Amoretti, S. Piligkos, G. A. Timco and R. E. P. Winpenny, Phys. Rev. Lett., 2005, 94, 207208/1-4; (i) A. Ardavan, O. Rival, J. J. L. Morton, S. J. Blundell, A. M. Tyryshkin, G. A. Timco and R. E. P. Winpenny, Phys. Rev. Lett. 2007, 98, 057201/1-4; (j) F. Troiani, M. Affronte, Chem. Soc. Rev., 2011, 40, 3119-3129; (k) L. Bogani and W. Wernsdorfer, Nat. Mater., 2008, 7, 179-186; (1) G. Maruccio, R. Cingolani and R. Rinaldi, J. Mater. Chem., 2004, 14, 542-554.

(a) W. Wernsdorfer, Adv. Chem. Phys. 2001, 118, 99; (b) D. Gatteschi and R. Sessoli, Angew. Chem. Int. Ed. 2003, 42, 268-297.

(a) G. Aromi and E. K. Brechin, Struct. Bonding (Berlin Ger.) 2006, 122, 1-67; (b) J-N. Rebilly and T. Mallah, Struct. Bonding (Berlin Ger.) 2006, 122, 103-131; (c) C. J. Milios, A. Vinslava, W. Wernsdorfer, S. Moggach, S. Parsons, S. P. Perlepes, G. Christou and E. K. Brechin, J. Am. Chem. Soc. 2007, 129, 2754-2755; (d) P. -H. Lin, T. J. Burchell, L. Ungur, L. F. Chibotaru, W. Wernsdorfer and M. Murugesu, Angew. Chem. Int. Ed. 2009, 48, 9489-9492.; (e) R. J. Blagg, C. A. Muryn, E. J. L. McInnes, F. Tuna and R. E. P. Winpenny, Angew. Chem. Int. Ed. 2011, 50, 6530-6533.

(a) J. Gómez-Segura, J. Veciana and D. Ruiz-Molina, Chem. Commun., 2007, 3699-3707; (b) M. Cavallini, M. Facchini, C. Albonetti and F. Biscarini, Phys. Chem. Chem. Phys., 2008, 10, 784-793; (c) G. Rogez, B. Donnio, E. Terazzi, J. -L. Gallani, J. -P. Kappler, J. -P. Bucher and M. Drillon, Adv. Mater. 2009, 21, 4323-4333; (d) A. Giusti, G. Charron, S. Mazerat, J.-D. Compain, P. Mialane, A. Dolbecq, E. Rivière, W. Wernsdorfer, R. Ngo Biboum, B. Keita, L. Nadjo, A. Filoramo, J.-P. Bourgoin and T. Mallah, Angew. Chem. Int. Ed. 2009, 48, 4949-4952; (e) A. Cornia, M. Mannini, P. Sainctavit and R. Sessoli, Chem. Soc. Rev., 2011, 40, 3076-3092; (f) B. Fleury, V. Huc, L. Catala, P. Jegou, L. Baraton, C. David, S. Palacin and T. Mallah, CrystEngComm, 2009, 11, 2192-2197.

6 See, for example: a) R. E. P. Winpenny, Adv. Inorg. Chem. 2001, 52, 1-111; (b) A. L. Dearden, S. Parsons and R. E. P. Winpenny, Angew. Chem., Int. Ed. 2001, 40, 151-154; (c) E. K. Brechin, Chem. Commun. 2005, 5141-5153; (d) S. J. Langley, M. Helliwell, R. Sessoli, P. Rosa, W. Wernsdorfer and R. E. P. Winpenny, Chem. Commun. 2005, 5029-5031; (e) D. Collison, E. J. L. McInnes and E. K. Brechin, Eur. J. Inorg. Chem. 2006, $2725-2733$. G. Mezei, C. M. Zaleski and V. L. Pecoraro, Chem. Rev., 2007, 107, 4933-5003.

8 (a) C. M. Zaleski, E. C. Depperman, J. W. Kampf, M. L. Kirk and V. L. Pecoraro, Angew. Chem. Int. ed. 2004, 43, 3912-3914; (b) C. M. Zaleski, E. C. Depperman, J. W. Kampf, M. L. Kirk and V. L. Pecoraro, Inorg. Chem., 2006, 45, 10022-10024; (c) C. M. Zaleski, J. W. Kampf, T. Mallah, M. L. Kirk and V. L. Pecoraro, Inorg. Chem., 2007, 46, 1954-1956; (d) T. T. Boron III, J. W. Kampf and V. L. Pecoraro, Inorg. Chem., 2010, 49, $9104-$ 9106; (e) C. M. Zaleski, S. Tricard, E. C. Depperman, W. Wernsdorfer, T. Mallah, M. L. Kirk and V. L. Pecoraro, Inorg. Chem., 2011, 50, 11348- 
11352; (f) J. Jankolovits , J. W. Kampf and V. L. Pecoraro, Inorg. Chem., 2013, 52, 5063-5076; (g) J. Jankolovits , J. W. Kampf and V. L. Pecoraro, Polyhedron, 2013, 52, 491-499.

(a) R. Sessoli, H.L. Tsai, A. Schake, S.Wang, J. B. Vincent, K. Folting, D. Gatteschi, G. Christou and D.N. Hendrickson, J. Am. Chem. Soc. 1993, 115, 1804-1816. (b) S. Wang, H.-L. Tsai, K. Folting, J. D. Martin, D. N. Hendrickson and G. Christou, J. Chem. Soc. Chem. Commun., 1994, 671673; (c) H. E. Toma, K. Araki, A. D. P. Alexiou, S. Nikolaou and S. Dovidauskas, Coord. Chem. Rev., 2001, 219, 187-234; (d) C. Cañada-Vilalta, E. Rumberger, E. Brechin, W. Wernsdorfer, K. Folting, E. R. Davidson, D. N. Hendrickson and G. Christou, J. Chem. Soc., Dalton Trans., 2002, 21, 4005-4010; (e) C. Cañada-Vilalta, T. A. O’Brien, M. Pink, E. R. Davidson and G. Christou, Inorg. Chem., 2003, 42, 7819-7829; (f) E. C. Sañudo, T. Cauchy, R. H. Laye, O. Roubeau, S. J. Teat and G. Aromí, Inorg. Chem., 2007, 46, 9045-9047; (g) Y.-Z. Zheng, M.-L. Tong, W. Xue, W.-X. Zhang, X.-Mi. Chen, F. Grandjean and G. J. Long, Angew. Chem., Int. Ed., 2007, 46, 6076-6080; (h) P. Albores and E. Rentschler, Dalton Trans. 2010, 39, 5005-5019; (i) G. A. Timco, T. B. Faust, F. Tuna and R. E. P. Winpenny, Chem. Soc. Rev., 2011, 40, 3067-3075; (j) Y.-Z. Zheng, M. Evangelisti and R. E. P. Winpenny, Chem. Sci., 2011, 2, 99-102; (k) A. Mondal, S. Durdevik, L.-M. Chamoreau, Y. Journaux, M. Julve, L. Lisnard, R. Lescouëzec, Chem. Commun. 2013, 49, 1181-1183; (1) G. F. S. Whitehead, F. Moro, G. A. Timco, W. Wernsdorfer, S. J. Teat, and R. E. P. Winpenny, Angew. Chem., Int. Ed., 2013, 52, 9932-9935.

10 (a) H. Miyasaka, K. Nakata, K. Sugiura, M. Yamashita and R. Clérac, Angew. Chem., Int. Ed., 2004, 43, 707-711; (b) L. Lecren, O. Roubeau, C. Coulon, Y.-G. Li, X. F. Le Goff, W. Wernsdorfer, H. Miyasaka and R. Clérac, J. Am. Chem. Soc., 2005, 127, 17353-17363 ; (c) H. Miyasaka, K. Nakata, L. Lecren, C. Coulon, Y. Nakazawa, T. Fujisaki, K. Sugiura, M. Yamashita and R. Clérac, J. Am. Chem. Soc., 2006, 128, 3770-3783; (d) H.B. Xu, B.-W. Wang, F. Pan, Z.-M. Wang and S. Gao, Angew. Chem. Int. Ed., 2007, 46, 7388-7392; (e) L. F. Jones, A. Prescimone, M. Evangelisti and E. K. Brechin, Chem. Commun., 2009, 2023-2025; (f) M. Haryono, M. Kalisz, R. Sibille, R. Lescouëzec, C. Fave, G. Trippe-Allard, Y. Li, M. Seuleiman, H. Rousselière, A. Majid Balkhy, J.-C. Lacroix and Y. Journaux, Dalton Trans., 2010, 39, 4751-4756; (g) B. Cordero, O. Roubeau, S.J. Teat and A. Escuer, Dalton Trans. 2011, 40, 7127-7129; (h) I.-R. Jeon and R. Clérac, Dalton Trans. 2012, 41, 9569-9586.

11 G. Aromì, A. S. Batsanov, P. Christian, M. Helliwell, A. Parkin, S. Parsons, A. A. Smith, G. A. Timco and R. E. P. Winpenny, Chem. Eur. J. 2003, 9, $5142-5161$

12 G. Chaboussant, R. Basler, H-U. Güdel, S. Ochsenbein, A. Parkin, S. Parsons, G. Rajamaran, A. Sieber, A. A. Smith, G. A. Timco and R. E. P. Winpenny, Dalton Trans. 2004, 2758-2766.

13 (a) C. J. Milios, E. Manessi-Zoupa, S. P. Perlepes, A. Terzis and C. P. Raptopoulos, Trans. Met. Chem., 2002, 27, 864-874; (b) Z. Tomkowicz, S. Ostrovsky, H. Muller-Bunz, A. J. H. Eltmimi, M. Rams, D. A. Brown and W. Haase, Inorg. Chem., 2008, 47, 6956-6963; (c) I. M. Rio-Echevarria, F. J. White, E. K. Brechin, P. A. Tasker and S. G. Harris, Chem. Commun., 2008, 4570-4572; (d). Y. Cao, Y. Chen, L. Li, D. Gao, W. Liu, H. Hu, W. Li, and Y. Li, Dalton Trans., 2013, 42, 10912-10918.

$14\left\{\mathrm{Co}_{2}\right.$ piv $\}$ as a starting material: (a) R. H. Laye, F. K. Larsen, J. Overgaard, C. A. Muryn, E. J. L. McInnes, E. Rentschler, V. Sanchez, S. J. Teat, H. U. Guedel, O. Waldmann, G. A. Timco and R. E. P. Winpenny, Chem. Comm., 2005, 1125-1127; (b) L. F. Jones, P. Jensen, B. Moubaraki, J. D. Cashion, K. J. Berry and K. S. Murray, Dalton Trans., 2005, 3344-3352; (c) E. C. Sanudo, T. B. Faust, C. A. Muryn, R. G. Pritchard, G. A. Timco and R. E. P. Winpenny, Inorg. Chem., 2009, 48, 9811-9818; (d) C. -F. Lee, D. A. Leigh, R. G. Pritchard, D. Schultz, S. J. Teat, G. A. Timco and R. E. P. Winpenny, Nature, 2009, 458, 314-318; (e) F. Kloewer, Y. Lan, J. Nehrkorn, O. Waldmann, C. E. Anson and A. K. Powell, Chem. Eur. J., 2009, 15, 7413-7422; (f) P. Albores and E. Rentschler, Angew. Chem., Int. Ed., 2009, 48, 9366-9370; (g) P. Albores and E. Rentschler, Dalton Trans. 2009, 2609-2615; (h) E. Y. Fursova, O. V. Kuznetsova, V. I. Ovcharenko, G. V. Romanenko, A. S. Bogomyakov, M. A. Kiskin and I. L. Eremenko, Russ. Chem. Bull., 2010, 59, 1152-1161; (i) B. Ballesteros, T. B. Faust, C. -F. Lee, D. A. Leigh, C. A. Muryn, R. G. Pritchard, D. Schultz, S. J.Teat, G. A. Timco and R. E. P. Winpenny, J. Am. Chem. Soc., 2010, 132, 15435-15444; (j) I. C. Lazzarini, L. Carrella, E. Rentschler and P. Albores, Polyhedron, 2012, 31, 779-788; (k) Y.-Z. Zheng, B. A. Breeze, G. A. Timco, F. Tuna, and R. E. P. Winpenny, Dalton Trans., 2010, 39, 6175-6177; 1. Y.-Z. Zheng, M. Evangelisti, F. Tuna, and R. E. P. Winpenny, J. Am. Chem. Soc., 2012, 134, 1057-1065; (m) B. Roy, M. Sutradhar, M. G. B. Drew, and E. Rentschler, Polyhedron, 2013, 51, 192-200; (n) P. Moreno, F. Tuna, R. G. Pritchard, A. C. Regan, R. E. P. Winpenny, and E. J. L. McInnes, Chem. Commun., 2013, 49, 3522-3524; (o) J. A. Sheikh, S. Goswami, A. Adhikary, and S. Konar, Inorg. Chem., 2013, 52, 4127-4129; (p) J. Feuersenger, D. Prodius, V. Mereacre, R. Clerac, C. E. Anson, and A. K. Powell, Polyhedron, 2013, 66, 257-263; (q) C. Plenk, T. Weyhermueller, and E. Rentschler, Chem. Commun., 2014, 50, 3871-3873; (r) A. V. Funes, L. Carrella, E. Rentschler, and P. Albores, Dalton Trans., 2014, 43, $2361-2364$.

$15\left\{\right.$ Ni $_{2}$ piv $\}$ as a starting material: (a) G. Aromí, A. R. Bell, M. Helliwell, J. Raftery, S. J. Teat, G. A. Timco, O. Roubeau and R. E. P. Winpenny, Chem. Eur. J., 2003, 9, 3024-3032; (b) G. Aromí, O. Roubeau, M. Helliwell, S. J. Teat and R. E. P. Winpenny, Dalton Trans., 2003, 3436-3442; (c) S. L. Heath, R. H. Laye, C. A. Muryn, N. Lima, R. Sessoli, R. Shaw, S. J. Teat, G. A. Timco and R. E. P. Winpenny, Angew. Chem., Int. Ed., 2004, 43, 6132-6135; (d) G. Aromi, A. Bell, S. J. Teat and R. E. P. Winpenny, Chem. Comm., 2005, 2927-2929; (e) A. Ghirri, A. Candini, M. Evangelisti, M. Affronte, S. Carretta, P. Santini, G. Amoretti, R. S. G. Davies, G. A. Timco and R. E. P. Winpenny, Phys. Rev. B, 2007, 76, 214405/1-8; (f) B. A. Breeze, M. Shanmugam, F. Tuna and R. E. P. Winpenny, Chem. Comm., 2007, 5185-5187; (g) Y.-Z. Zheng, M. Evangelisti and R. E. P. Winpenny, Angew. Chem., Int. Ed., 2011, 50, 3692-3695; (h) Y.-Z. Zheng, M. Evangelisti, and R. E. P. Winpenny, Angew. Chem., Int. Ed., 2011, 50, 3692-3695; (i) H. Rath, G. A. Timco, V. Corradini, A. Ghirri, P. del, A. Fernandez, R. G. Pritchard, C. A. Muryn, M. Affronte, and R. E. P. Winpenny, Chem. Commun., 2013, 49, 3404-3406; (j) G. F. S. Whitehead, B. Cross, L. Carthy, V. A. Milway, H. Rath, A. Fernandez, S. L. Heath, C. A. Muryn, R. G. Pritchard, S. J. Teat, G. A. Timco, and R. E. P. Winpenny, Chem. Commun., 2013, 49, 7195-7197; (k) E. M. Pineda, F. Tuna, Y.-Z. Zheng, R. E. P. Winpenny, and E. J. L. McInnes, Inorg. Chem., 2013, 52, 13702-13707; (1) M. Sutradhar, T. R. Barman, and E. Rentschler, Inorg. Chem. Comm., 2014, 39, 140-143.

${ }_{16}\left\{M_{2}\right.$ piv $\}$ as a starting material: (a) G. Aromi, A. S. Batsanov, P. Christian, M. Helliwell, O. Roubeau, G. A. Timco and R. E. P. Winpenny, Dalton Trans., 2003, 4466-4471; (b) F. K. Larsen, E. J. L. McInnes, H. El Mkami, J. Overgaard, S. Piligkos, G. Rajaraman, E. Rentschler, A. A. Smith, G. M. Smith, V. Boote, M. Jennings, G. A. Timco and R. E. P. Winpenny, Angew. Chem., Int. Ed. 2003, 42, 101-105; (c) M. Affronte, I. Casson, M. Evangelisti, A. Candini, S. Carretta, C. A. Muryn, S. J. Teat, G. A. Timco, W. Wernsdorfer and R. E. P. Winpenny, Angew. Chem. Int. Ed., 2005, 44, 6496-6500; (d) I. G. Fomina, G. G. Aleksandrov, Zh. V. Dobrokhotova, O. Yu. Proshenkina, M. A. Kiskin, Yu. A. Velikodnyi, V. N. Ikorskii, V. M. Novotortsev and I. L. Eremenko, Russ. Chem. Bull., 2006, 55, 1909-1919; (e) P. Albores, J. Seeman and E. Rentschler, Dalton Trans., 2009, 76607668; (f) I. G. Fomina, Zh. V. Dobrokhotova, G. G. Aleksandrov, M. L. Kovba, V. I. Zhilov, A. S. Bogomyakov, V. M. Novotortsev and I. L. Eremenko, Russ. Chem. Bull., 2010, 59, 699-705; (g) T. C. Stamatatos, C. P. Raptopoulou, S. P. Perlepes and A. K. Boudalis, Polyhedron, 2011, 30, 3026-3033; (h) L. M. Carrella, D. Schollmeyer, and E. Rentschler, Z. Anorg. Allg. Chem., 2011, 637, 1756-1760; (i) P. Albores, C. Plenk, and E. Rentschler, Inorg. Chem., 2012, 51, 8373-8384; (j) J. A. Sheikh, A. Adhikary, H. S. Jena, S. Biswas, and S. Konar, Inorg. Chem., 2014, 53, 16061613 .

17 M. Murrie, Chem. Soc. Rev., 2010, 39, 1986-1995.

18 G. E. Kostakis, S. P. Perlepes, V. A. Blatov, D. M. Proserpio, A. K. Powell, Coord. Chem. Rev., 2012, 256, 1246-1278. 
19 See for example : (a) N. S. McCool, D. M. Robinson, J. E. Sheats, and G. C. Dismukes, J. Am. Chem. Soc., 2011, 133, 11446-11449; (b) T. C. Davenport, H. S. Ahn, M. S. Ziegler, and T. D. Tilley, Chem. Commun., 2014, 50, 6326-6329 ; (c) H. Lv, J. Song, Y. V. Geletii, J. W. Vickers, J. M. Sumliner, D. G. Musaev, P. Kögerler, P. F. Zhuk, J. Bacsa, G. Zhu, and C. L. Hill, J. Am. Chem. Soc., 2014, 136, $9268-9271$.

20 D. Griffith, K. Krot, J. Comiskey, K. B. Nolan and C. J. Marmion, Dalton Trans. 2008, 137-147.

21 BrukerAXS Inc, Madison, Wisconsin, USA.

22 BrukerAXS Inc, Madison, Wisconsin, USA; G. M. Sheldrick, Acta Cryst. 2008 A64, 112; R. H. Blessing, Acta Cryst. 1995, A51, 33

23 J. A. Nelder and R. Mead, Computer Journal, 1965, 7, 308-313.

24 S. B. Jedner, H. Schwoppe, H. Nimir, A. Rompel, D. A. Brown, B. Krebs, Inorg. Chim. Acta, 2002, 340, $181-186$.

$25\left\{\mathrm{Co}_{4}\left(\mu_{3}-\mathrm{O}\right)_{2}\right\}$ : (a) M. A. Golubichnaya, A. A. Sidorov, I. G. Fomina, M. O. Ponina, S. M. Deomidov, S. E. Nefedov, I. L. Eremenko and I. I. Moiseev, Russ. Chem. Bull., 1999, 1751-1756; (b) G. Aromi, A. S. Batsanov, P. Christian, M. Helliwell, A. Parkin, S. Parsons, A. A. Smith, G. A. Timco and R. E. P. Winpenny, Chem. -Eur. J., 2003, 9, 5142-5161; (c) V. Gorbunov, T. O. Denisova, E. V. Amel'chenkova and S. E. Nefedov, Russ. J. Inorg. Chem., 2006, 51, 1581-1586.

$26\left\{\mathrm{Ni}_{4}\left(\mu_{3}-\mathrm{O}\right)_{2}\right\}$ : (a) J. Lisowski, P. Starynowicz, A. Jezierski and Z. Siatecki, Polyhedron, 1996 ,15, 3589-3593; (b) A. A. Sidorov, P. V. Danilov, S. E. Nefedov, M. A. Golubnichaya, I. G. Fomina, O. G. Ellert, V. M. Novotortsev and I. L. Eremenko, Russ. J. Inorg. Chem., 1998, 43, 930; (c) A. A. Sidorov, S. A. Deomidov, S. E. Nefedov, I. G. Fomina, P. V. Danilov, V. M. Novotortsev, O. G. Volkov, V. N. Ikorskii and I. L. Eremenko, Russ. J. Inorg. Chem., 1999, 44, 396; (d) V. V. Pavlishchuk, S. V. Kolotilov, A. W. Addison, M. J. Prushan, D. Schollmeyer, L. K. Thompson and E. A. Goreshnik, Angew. Chem., Int. Ed., 2001 , 40, 4734-4737; (e) A. A. Sidorov, I. G. Fomina, S. S. Talismanov, G. G. Aleksandrov, V. M. Novotortsev, S. E. Nefedov and I. L. Eremenko, Coord. Chem., 2001, 27, 548-559; (f) V. V. Pavlishchuk, S. V. Kolotilov, A. W. Addison, M. J. Prushan, D. Schollmeyer, L. K. Thompson, T. Weyhermuller and E. A. Goreshnik, Dalton Trans., 2003, 1587-1595; (g) G. Chaboussant, R. Basler, H. -U. Gudel, S. T. Ochsenbein, A. Parkin, S. Parsons, G. Rajaraman, A. Sieber, A. A. Smith, G. A. Timco and R. E. P. Winpenny, Dalton Trans., 2004, 27582766; (h) J. Esteban, E. Ruiz, M. Font-Bardia, T. Calvet, A. Escuer, Chem. Eur. J., 2012, 18, 3637-3648.

$27\left\{\mathrm{Co}_{4}\left(\mu_{3}-\mathrm{O}\right)_{2}(\mu-O, N, X)_{4}\right\}$ : (a) R. M. Buchanan, B. J. Fitzgerald and C. G. Pierpont, Inorg. Chem., 1979, 18, 3439-3444; (b) J. A. Bertrand, E. Fujita and D. G. VanDerveer, Inorg. Chem., 1979, 18, 230-233; (c) M. G. Barandika, Z. Serna, R. Cortes, L. Lezama, M. K. Urtiaga, M. I. Arriortua and T. Rojo, Chem. Commun., 2001, 45-46; (d) Z. E. Serna, M. K. Urtiaga, M. G. Barandika, R. Cortes, S. Martin, L. Lezama, M. I. Arriortua and T. Rojo, Inorg. Chem., 2001 ,40, 4550-4555; (e) P. Werndrup and V. G. Kessler, J. Chem. Soc., Dalton Trans., 2001, 574-579; (f) G. S. Papaefstathiou, A. Escuer, C. P. Raptopoulou, A. Terzis, S. P. Perlepes and R. Vicente, Eur. J. Inorg. Chem., 2001, 1567-1574; (g) G. S. Papaefstathiou, A. Escuer, M. Font-Bardia, S. P. Perlepes, X. Solans and R. Vicente, Polyhedron, 2002, 21, 2027-2032; (h) N. E. Borisova, Yu. A. Ustynyuk, M. D. Reshetova, G. G. Aleksandrov, I. L. Eremenko and I. I. Moiseev, Mendeleev Commun., 2003, 202-204; (i) G. A. Seisenbaeva, M. Kritikos and V. G.Kessler, Polyhedron, 2003, 22, 2581-2586; (j) P. King, R. Clerac, W. Wernsdorfer, C. E. Anson and A. K. Powell, Dalton Trans., 2004, 2670-2676; (k) S. G. Telfer, R. Kuroda, J. Lefebvre and D. B. Leznoff, Inorg. Chem., 2006, 45, 4592-4601; (1) D. Mandal and D. Ray, Inorg. Chem. Commun., 2007, 10, 1202-1205; (m) S.-H. Zhang, Y.-M. Jiang and Z. Min Liu, J. Coord. Chem., 2008, 61, 1927-1934; (n) S. S. Tandon, S. D. Bunge, R. Rakosi, Z. Xu and L. K. Thompson, Dalton Trans., 2009, 6536-6551; (o) C.-M. Liu, Y. Song, D.-Q. Zhang, Inorg. Chem. Commun., 2010, 13, 160-162; (p) S.-Y. Zhang, B. Xu, L. Zheng, W. Chen, Y. Li and W. Li, Inorg. Chim. Acta, 2011, 367, 44-50; (q) S. Banerjee, M. Nandy, S. Sen, S. Mandal, G. M. Rosair, A. M. Z. Slawin, C. J. G. Garcia, J. M. Clemente-Juan, E. Zangrando, N. Guidolin and S. Mitra, Dalton Trans., 2011, 40, 1652-1661; (r) R. Pattacini, P. Teo, J. Zhang, Y. Lan, A. K. Powell, J. Nehrkorn, O. Waldmann, T. S. A. Hor, P. Braunstein, Dalton Trans., 2011, 40, 10526-10534; (s) S. R. Hosseinian, V. Tangoulis, M. Meneiaou, C. P. Raptopoulou, V. Psycharis, C. Dendrinou-Samara, Dalton Trans., 2013, 42, 5355-5366; (t) H.-H. Chen, J. Yang, Y.-Y. liu, J.-F. Ma, CrystEngComm, 2013, 15, 5168-5178.

$28\left\{\mathrm{Ni}_{4}\left(\mu_{3}-\mathrm{O}\right)_{2}(\mu-O, N, X)_{4}\right\}$ : (a) Z. E. Serna, L. Lezama, M. K. Urtiaga, M. I. Arriortua, M. G. Barandika, R. Cortes and T. Rojo, Angew. Chem., Int. Ed., 2000, 39, 344-347; (b) Z. E.Serna, M. G. Barandika, R. Cortes, M. K. Urtiaga, G. Barberis and T. Rojo, J. Chem. Soc., Dalton Trans., 2000, 29-34; (c) P. King, R. Clerac, W. Wernsdorfer, C. E. Anson and A. K. Powell, Dalton Trans., 2004, 2670-2676; (d) M. Koikawa, M. Ohba and T. Tokii, Polyhedron, 2005, 24, 2257-2262; (e) J. Langer, H. Gorls, G. Gillies and D. Walther, Z. Anorg. Allg. Chem., 2005, 631, 2719-2726; (f) J. Reglinski, M. K. Taylor and A. R. Kennedy, Inorg. Chem. Commun., 2006, 9, 736-739; (g) C. G. Efthymiou, C. P. Raptopoulou, A. Terzis, R. Boca, M. Korabic, J. Mrozinski, S. P. Perlepes and E. G. Bakalbassis, Eur. J. Inorg. Chem., 2006, 2236-2252; (h) D. -Y. Wu, W. Huang, W. -J. Hua, Y. Song, C. -Y. Duan, S. -H. Li and Q. -J. Meng, Dalton Trans., 2007, 1838-1845; (i) S. S. Tandon, S. D. Bunge, R. Rakosi, Z. Xu and L. K. Thompson, Dalton Trans., 2009, 6536-6551; (j) K. Wang, M. Shen and W. -H. Sun, Polyhedron, 2010, 29, 564-568; (k) M. Delferro, M. P. Weberski, B. A. Rodriguez and T. J. Marks, Acta Crystallogr., Sect. E: Struct. Rep. Online, 2010, 66, m257; (1) Z. Serna, N. De la Pinta, M. K. Urtiaga, L. Lezama, G. Madariaga, J. M. Clemente-Juan, E. Coronado, R. Cortes, Inorg. Chem., 2010, 49, 11541-11549; (m) S. -Y. Lin, G. -F. Xu, L. Zhao, Y. -N. Guo, J. Tang, Q. -L. Wang and G. -X. Liu, Inorg. Chim. Acta, 2011, 373, 173-178; (n) A. D. Katsenis, V. G. Kessler and G. S. Papaefstathiou, Dalton Trans., 2011, 40, 4590-4598; (o) S. Banerjee, M. Nandy, S. Sen, S. Mandal, G. M. Rosair, A. M. Z. Slawin, C. J. G. Garcia, J. M. Clemente-Juan, E. Zangrando, N. Guidolin and S. Mitra, Dalton Trans., 2011, 40, 1652-1661; (p) S. Liu, S. Wang, F. Cao, H. Fu, D. Li, J. Dou, RSC Advances, 2012, 2, 1310-1313; (q) S.-Y. Tan, F. Chang, Y.-P. Gao, Acta Crystallogr., Sect. E:Struct. Rep. Online, 2012, 68, m150.

29 (a) G. Psomas, C. Dendrinou-Samara, M. Alexiou, A. Tsohos, C. P. Raptopoulou, A. Terzis and D. P. Kessissoglou, Inorg. Chem., 1998, 37, 65566557; (b) D. Gaynor, Z. A. Starikova, S. Ostrovsky, W. Haase and K. B. Nolan, Chem. Commun., 2002, 506-507; (c) E. Gumienna-Kontecka, I. A. Golenya, N. M. Dudarenko, A. Dobosz, M. Haukka, I. O. Fritsky and J. Swiatek-Kozlowska, New J. Chem., 2007, 31, 1798-1805; (d) C. M. Zaleski, J. W. Kampf, T. Mallah, M. L. Kirk and V. L. Pecoraro, Inorg. Chem., 2007, 46, 1954-1956; (e) A. V. Pavlishchuk, S. V. Kolotilov, M. Zeller, L. K. Thompson, I. O. Fritsky, A. W. Addison and A. D. Hunter, Eur. J. Inorg. Chem., 2010, 4851-4858.

30 (a) D. A. Brown, W. Errington, N. J. Fitzpatrick, W. K. Glass, T. J. Kemp, H. Nimir and A. T. Ryan, Chem. Commun., 2002, 1210-1211; (b) D. A. Brown, N. J. Fitzpatrick, H. Muller-Bunz and A. T. Ryan, Inorg. Chem., 2006, 45, 4497-4507; (c) P. Buglyo and E. Farkas, Dalton Trans., 2009, 8063-8070; (d) A. Z. Eltayeb, H. I. Nimir, D. A. Brown, Y. Lan, C. E. Anson and A. K. Powell, Inorg. Chim. Acta, 2010, 363, 899-904.

31 M. E. Lines, J. Chem. Phys., 1971, 55, 2977-2984,

32 (a) H. Sakiyama, R. Ito, H. Kumagai, K. Inoue, M. Sakamoto, Y. Nishida and M. Yamasaki, Eur. J. Inorg. Chem., 2001, 2027-2032; (b) F. Lloret, M. Julve, J. Cano, R. Ruiz-Garcl̀a and E. Pardo, Inorg. Chim. Acta, 2008, 361, 3432-3445; (c) S. Ostrovsky, Z. Tomkowicz and W. Haase, Coord. Chem. Rev., 2009, 253, 2363-2375.

33 (a) R. M. Golding, Applied wave mechanics Van Nostrand Co, London, 1969, ch. 6, pp. 239; (b) O. Kahn, Molecular Magnetism, VCH Publishers Inc, New York, 1993, ch. 3, p38.

34 (a) Y. Nishida and S. Kida, J. Chem. Soc., Dalton Trans., 1986, 2633-2640; (b) T. Mallah, M. L. Boillot, O. Kahn, J. Gouteron, S. Jeannin and Y. Jeannin, Inorg. Chem., 1986, 25, 3058-3065.

35 R. Boča, Coord. Chem. Rev., 2004, 248, 757-815.

36 Y. Journaux and O. Kahn, J. Chem. Soc., Dalton Trans., 1979, 1575-1580. 